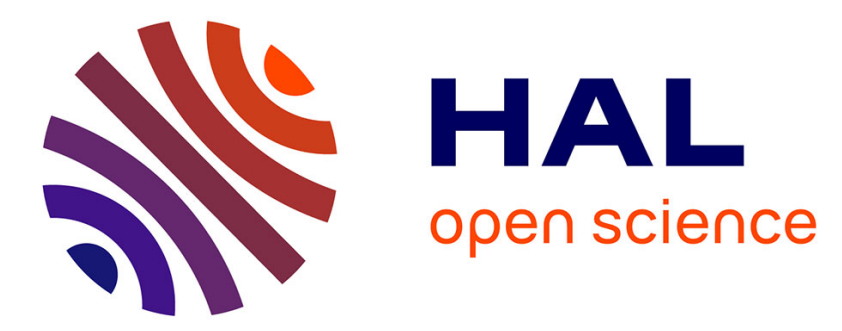

\title{
A combination of in-silico and SAR studies to identify binding hot spots of Bcl-xL inhibitors
}

Nicolas Levoin, Duc Duy Vo, Fabien Gautier, Sophie Barillé-Nion, Philippe Juin, Olivier Tasseau, René Grée

\section{- To cite this version:}

Nicolas Levoin, Duc Duy Vo, Fabien Gautier, Sophie Barillé-Nion, Philippe Juin, et al.. A combination of in-silico and SAR studies to identify binding hot spots of Bcl-xL inhibitors. Bioorganic and Medicinal Chemistry, 2015, 23 (8), pp.1747-1757. 10.1016/j.bmc.2015.02.060 . hal-01133213

\section{HAL Id: hal-01133213 \\ https://hal-univ-rennes1.archives-ouvertes.fr/hal-01133213}

Submitted on 29 Oct 2015

HAL is a multi-disciplinary open access archive for the deposit and dissemination of scientific research documents, whether they are published or not. The documents may come from teaching and research institutions in France or abroad, or from public or private research centers.
L'archive ouverte pluridisciplinaire HAL, est destinée au dépôt et à la diffusion de documents scientifiques de niveau recherche, publiés ou non, émanant des établissements d'enseignement et de recherche français ou étrangers, des laboratoires publics ou privés. 


\section{A combination of in-silico and SAR studies to identify binding hot spots of Bcl-xL inhibitors}

Nicolas Levoin ${ }^{1 *}$ Duc Duy Vo ${ }^{2}$, Fabien Gautier ${ }^{3,4,5}$, Sophie Barillé-Nion ${ }^{3}$, Philippe Juin ${ }^{3,4}$,

Olivier Tasseau ${ }^{2}$ and René Grée ${ }^{2}$

${ }^{1}$ Bioprojet-Biotech, 4 rue du Chesnay Beauregard, BP 96205, 35762 Saint Grégoire, France.

${ }^{2}$ Université de Rennes 1, Institut des Sciences Chimiques de Rennes, CNRS UMR 6226, Avenue du Général Leclerc, 35042 Rennes Cedex, France.

${ }^{3}$ UMR 892 INSERM 16299 CNRS / Université de Nantes, Team 8 "Cell survival and tumor escape in breast cancer", Institut de Recherche Thérapeutique de l'Université de Nantes, 8 quai Moncousu, BP 70721, 44007 Nantes Cedex 1, France.

${ }^{4}$ Institut de Cancérologie de l'Ouest, Centre de Lutte contre le Cancer René Gauducheau, Boulevard Jacques Monod, 44805 Saint Herblain-Nantes Cedex, France.

${ }^{5}$ Plateforme IMPACT ${ }^{\circledR}$, Biogenouest Institut de Recherche Thérapeutique de l'Université de Nantes, 8, quai Moncousu, BP 7072144007 Nantes Cedex 1, France.

Corresponding author : Nicolas Levoin n.levoin@bioprojet.com tel :0299280454 


\begin{abstract}
Inhibition of Bcl-2 family protein-protein interactions (PPI) is a very promising direction in cancer chemotherapy. Hence over the last decade, many medicinal chemistry studies endeavoured to discover drug candidates, and a wealth of chemical scaffolds with striking chemical diversity was reported as Bcl-xL inhibitors. This raises the question of whether all these molecules could occupy a unique binding site, or rather discrete pockets of the protein surface.

To test if small and chemically diverse Bcl-xL inhibitors are likely to bind a single pocket, and to identify which pocket, we used a battery of computational and modeling approaches. We first checked that the large dataset of Bcl-xL inhibitors we built can actually fit to a universal pharmacophore. Then we defined the probable binding hot spots of interaction through comparison of crystal structures, as well as virtual fragment screening. Finally, new analogues of small polyphenol derivatives were synthesized to precisely probe a hydrogen bond suggested by docking experiments. Bcl-xL inhibition potency of these products confirmed the predicted binding mode.

This combination of X-ray structure exploration, molecular modeling studies and medicinal chemistry supports that all these small Bcl-xL inhibitors occupy the same hot spot of interaction. The identification of this binding site should help the design and optimization of small PPI Bcl-xL inhibitors.
\end{abstract}




\section{Introduction}

Considered as exotic or as purely intellectual exercise few years ago, protein protein interactions (PPI) are now the subject of intensive prospecting in many biological and pharmaceutical projects. ${ }^{1}$ Although still considered as a very difficult field in medicinal chemistry, examples of PPI inhibitors have recently grown. ${ }^{2,3}$ They received significant attention in cancer drug discovery, because PPI are seen as signalling nodes, linking networks that relay oncogenic signals. ${ }^{4}$

Members of the Bcl-2 proteins family (Bcl-2, Bcl-xL, Bcl-w, Mcl-1), which interact with $\mathrm{BH} 3$ domains, are among the most studied protein targets in that area. They have indeed critical implication in apoptosis and cell proliferation pathways, and $\mathrm{Bcl}-\mathrm{xL}$ is considered as a robust biomarker for some cancers. ${ }^{5,6}$ Drug candidates emerged from these investigations, and the Bcl-2 family inhibitor Navitoclax for example, is currently evaluated in phase 2 clinical trials. ${ }^{7}$ Moreover, a large scale genomic analysis showed that Bcl-xL mRNA and protein levels were associated with drug sensitivity of proliferating cells, suggesting that Bcl-xL could be implicated in resistance to chemotherapies. ${ }^{8}$ Hence Navitoclax potentiates the activity of chemotherapeutic regimens. ${ }^{9}$

Many Bcl-xL inhibitors covered by a wealth of molecular scaffolds have been described in recent years. ${ }^{10}$ The chemical diversity of published molecules is actually striking, from peptides to small drug-like molecules. Inhibition of Bcl-xL and BH3-domains interaction were first obtained with BH3-mimetics. ${ }^{11,12,13,14,15}$ Then chemically-modified peptides were described, such as stabilized alpha-helix of Bcl-2 domain (SAHBs). ${ }^{16,17}$ Due to the limited pharmaceutical potential of peptides, small molecule inhibitors were avidly sought. This led to the discovery of natural molecules, polyphenols or alkaloids, ${ }^{18,19}$ and many synthetic analogs (Fig. 1). More recently, fragment-based drug design approaches were used to circumvent the synthetic complexity of natural products. ${ }^{20,21}$ So different classes of molecules show little similarity, and question the nature of their binding site. Do these different ligands bind to discrete subcavities of Bcl-xL protein surface, or do they share a common and unique binding site?

The binding site of some inhibitors has been unequivocally identified by experimental studies, using X-ray or NMR structure solving. Unfortunately, these studies were undertaken with large molecules, without clear similarity with smaller ligands such as natural products. ${ }^{22} \mathrm{Co}-$ crystallized large molecules occupy different subsites of the $\mathrm{BH} 3$ groove. Only portions of inhibitors overlap (Fig. 1), which makes difficult the definition of a shared protein interface, if any.

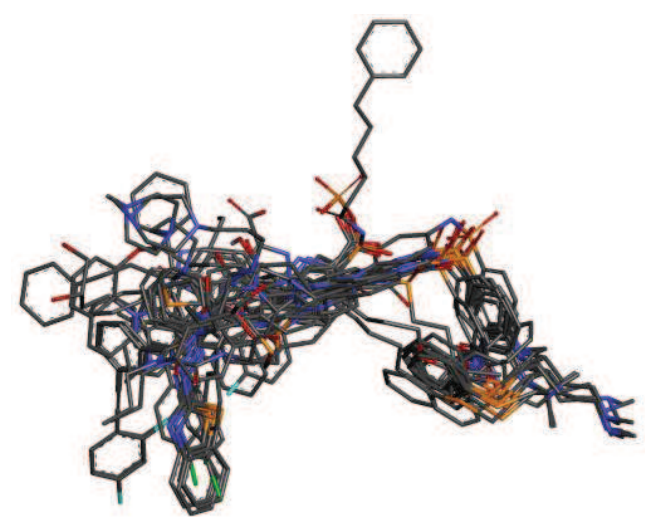

Fig. 1 Superimposition of co-crystallized inhibitors of Bcl-xL. ${ }^{22}$

One can suppose that these wide-ranging protein-ligand contacts are not mandatory. It is known actually that only fraction of ligands is responsible for their affinity, and interaction 
energy lies essentially on so-called hot spot of binding. ${ }^{23,24}$ Not all chemical groups of a ligand participate in the binding energy, or not in a linear and additive mode, giving rise to the concept of ligand efficiency (LE) ${ }^{25}$

It is probable that small Bcl-xL inhibitors occupy the hot spots of binding, explaining their high affinity compared with their limited size. To conceive smaller Bcl-xL inhibitors, with higher LE than current molecules, it is thus decisive to know what part of the large molecules makes a significant contribution to the binding energy, and in which protein pocket(s) the binding hot spots are located.

This work intends to answer two interwoven questions: first, is there a unique binding site for small size Bcl-xL inhibitors? Secondly, is it possible to identify hot spot(s) of binding for known inhibitors? We tackled these questions by using a combination of crystal structure analysis, molecular modeling experiments and hypothese validation through novel compounds synthesis. 


\section{Results and Discussion}

\subsection{Is a unique binding site possible? Building of a pharmacophore model}

A good way to address the first question is to test if molecular scaffolds of small Bcl-xL inhibitors can fit to a unique pharmacophore model. We used a compilation of known inhibitors with wide chemical diversity to build hypotheses (Fig.2).

\begin{tabular}{|c|c|c|c|c|c|c|c|}
\hline name & structure & $K i^{\$}$ & reference & name & structure & $K i^{\$}$ & reference \\
\hline & & (nM) & & & & $(n M)$ & \\
\hline $19-93$ & & 930 & 29 & TM-179 & & 1100 & 32 \\
\hline BCL-LZH-040 & & 17 & 30 & TW-37 & & 1100 & 53 \\
\hline $\mathrm{BH} 3 \mathrm{I}-1$ & & 2400 & 26 & wei2 & & 2018 & 34 \\
\hline BH3-I2 & & 4100 & 26 & wei6a & & 344 & 34 \\
\hline Bl21-C6 & & 500 & 28 & wei6c & & 1636 & 34 \\
\hline biflavonoid & & 00 & 32 & wei6d & & 6900 & 34 \\
\hline DCBL55 & & 3400 & 27 & wei6e & & 982 & 34 \\
\hline flavonoid & & 1780 & 32 & wei6i & & 185 & 34 \\
\hline gossypol & & 1000 & 33 & wei7 & & 185 & 34 \\
\hline
\end{tabular}

Fig. 2 Reference Bcl-xL PPI inhibitors used to build the pharmacophore model. ${ }^{\$}$ If Ki was not available, IC50 is reported instead. . $^{27,28,29,30,31,32,33,34}$

Using automatic pharmacophore generation and further refinements of the hypotheses, a fivefeature pharmacophore can actually be defined using this dataset. The model can be described as a four-branched star. Three branches are constituted by three hydrogen bond (HB) vectors originating from the centre of the star, the last branch being drawn by two hydrophobic spheres, slightly out of the plane (Fig. 3A). A distance of $3.3 \AA$ is measured between the lipophilic spheres, and $6.5 \AA$ between the centroid of HB vectors and the first lipophilic sphere. As examples, Fig. 3B shows different scaffolds conformed to the pharmacophore. This model is close to a previously decribed pharmacophore based on peptide ligands of Bcl$\mathrm{xL} .{ }^{35}$ In this four feature pharmacophore ( $2 \mathrm{HB}$ and 2 hydrophobic groups), a distance of about $5 \AA$ can be estimated for $\mathrm{d}_{1}$, and $6 \AA$ for $\mathrm{d}_{2}$. 

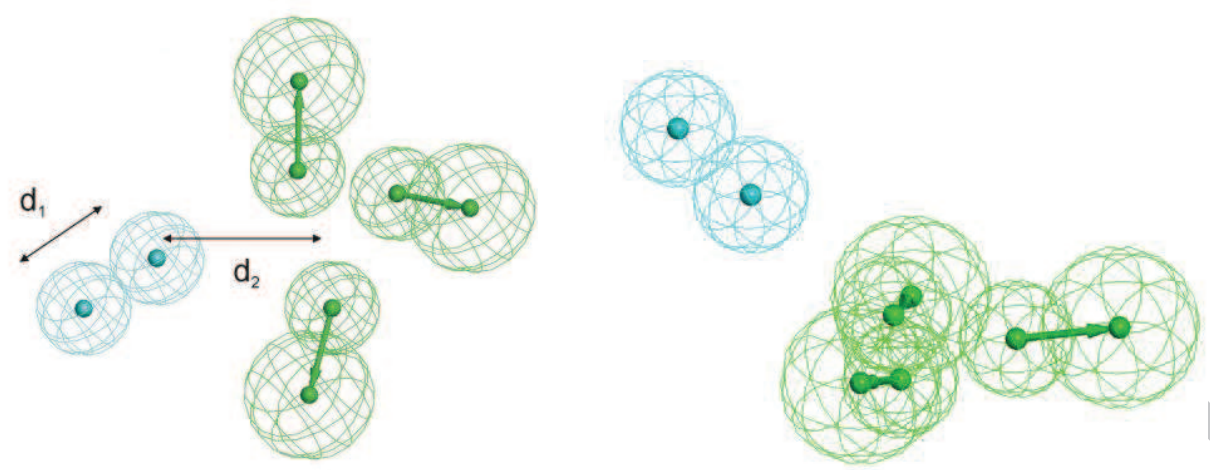

Fig. 3A Pharmacophore of Bcl-xL PPI inhibitors built using the Fig. 2 dataset, viewed from above the plane (left) and in profile (right). Lipophilic features are represented by blue spheres, HB acceptor by green vectors. $\mathrm{d}_{1}=3.3 \AA, \mathrm{d}_{2}=6.5 \AA$

Fig. 3B Example of Bcl-xL inhibitors superimposed to the pharmacophore. From left to right, and up to down: TM-179, 19-93, wei6i, BI21-C6 (Fig. 2)
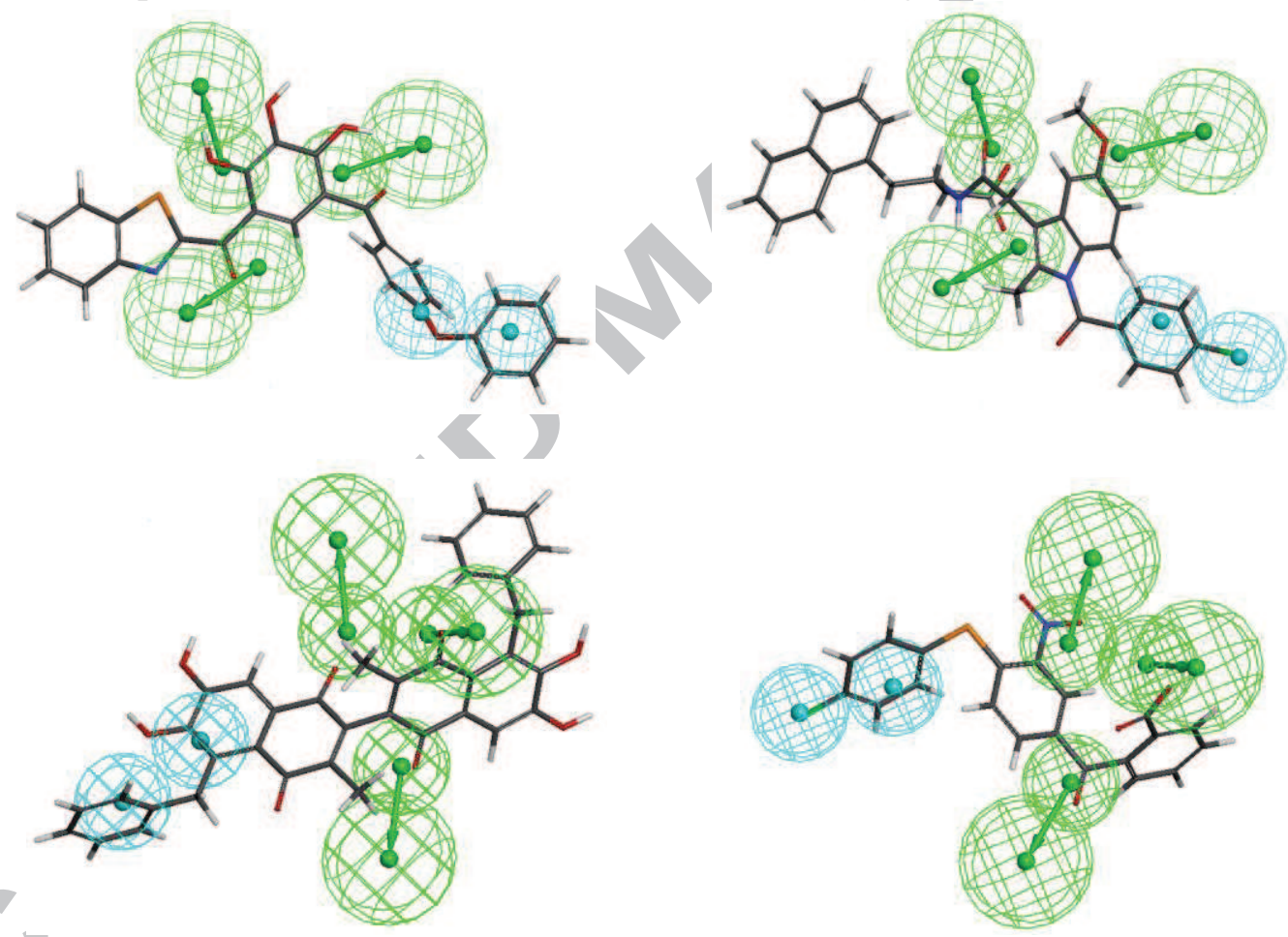

If all inhibitors had not been able to match the pharmacophore, we would have concluded that they bind to different sites of the protein surface, each molecular scaffold having its own cavity. Here, even if we can't be definitely assertive, the ability of all ligands to define a unique pharmacophore argues in favour of the one-site hypothesis.

\subsection{Identification of binding hot spots with co-crystallized Bcl-xL complexes.}

To test if the above conclusion is compatible with available Bcl-xL protein structures, we turned towards structure-based information, and we complemented these observations with molecular modelling experiments. 
By superimposing experimental 3D structures of Bcl-xL, we observed 2 hydrophobic cavities that accommodate lipophilic amino acids conserved among peptide-Bcl-xL complexes (Fig. $4)$. These clusters are formed by one hydrophobic amino acid per helix turn, with a mean pitch of $6.2 \AA$ (cluster 1) and $7.5 \AA$ (cluster 2). Peptide cluster 1 is surrounded by Bcl-xL residues Leu108, Leu111, Phe97, Phe105, Leu130 and Phe146. Cluster 2 is lined with Ala93, Tyr101, Val141 and Phe191. Flanked by the clusters, a triad basic-hydrophobic-acid is also conserved. The basic residue (usually Arg) form a salt bridge with Glu129 of Bcl-xL, and the acidic Asp with Arg139. Bak peptide lacks the basic residue (Ala instead), Soul peptide has no acidic amino acid, and they don't form any compensating salt bridge. So it is tempting to see the conserved clusters of hydrophobic amino acids and the corresponding cavities in Bcl$\mathrm{xL}$ as the main binding hot spots. This is in agreement with previous free energy decomposition analysis, showing that these hydrophobic residues are crucial for peptides interaction. $^{36}$
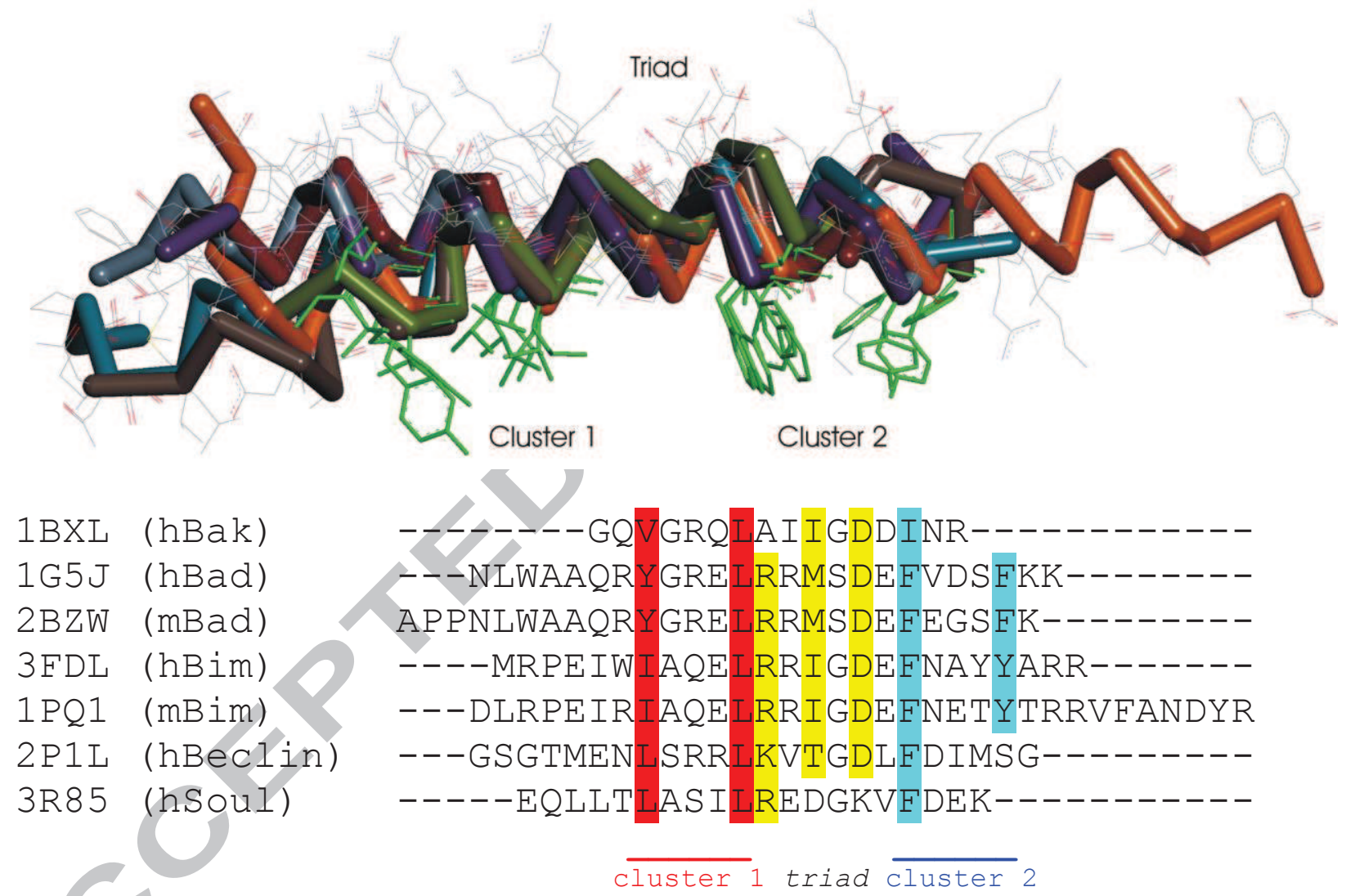

Fig. 4 Superimposition of BH3 peptides bound and co-crystallized with Bcl-xL. The sequence alignment is based on Bcl-xL protein structure superposition. Two hydrophobic clusters appear, separated by a nearly conserved triad Arg-Hydrophobic-Asp.

The first Bcl-xL small molecule complex was obtained by fragments library cocrystallisation. ${ }^{20}$ Two mostly hydrophobic fragments were found to occupy pockets lined with Leu108, Ala114, Phe115 and Leu130 (called site 1 in the seminal study ${ }^{20}$ ), and Ala142, Arg165, Tyr195 (called site2). Site 1 corresponds to a region encompassing the second hydrophobic residue of the above triad and cluster 1 , site 2 corresponds to cluster 2 . Hence comparison of peptides and fragments crystal structures supports strongly that site 1 and site 2 constitute binding hot spot for Bcl-xL. 


\subsection{Identification of binding hot spots by virtual fragment screening.}

The importance of sites 1 and 2 was confirmed by virtual fragment screening. Indeed, there is substantial evidence that hot spots may be characterized by their ability to bind a variety of small molecules such as solvents, and that hot spots can be reliably determined by computational means. ${ }^{37,38}$ Methane and cyclohexane probes screened on the complete protein surface clustered actually on these 2 cavities (Fig. 5). Site 2 is more populated by cyclohexane than site 1, and binding energy calculations suggest that site 2 could be the most important hot spot. Conversely, ${ }^{39}$ water probes were excluded from these cavities (Table 1).
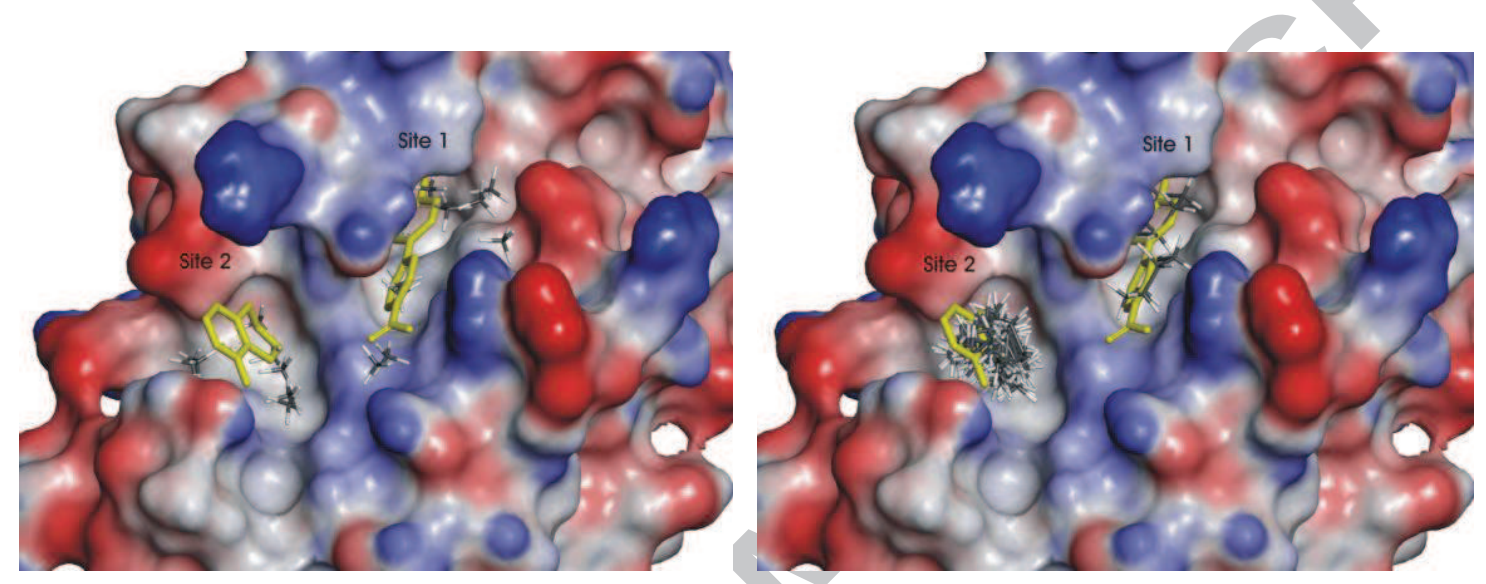

Fig. 5 Multiple Copy Simultaneous Search (MCSS) ${ }^{40}$ with hydrophobic fragments on Bcl-xL protein surface. Cyclohexane clustered on site 1 and site 2 (left), as well as methane probe (right). Co-crystallized fragments ${ }^{20}$ are in yellow. 


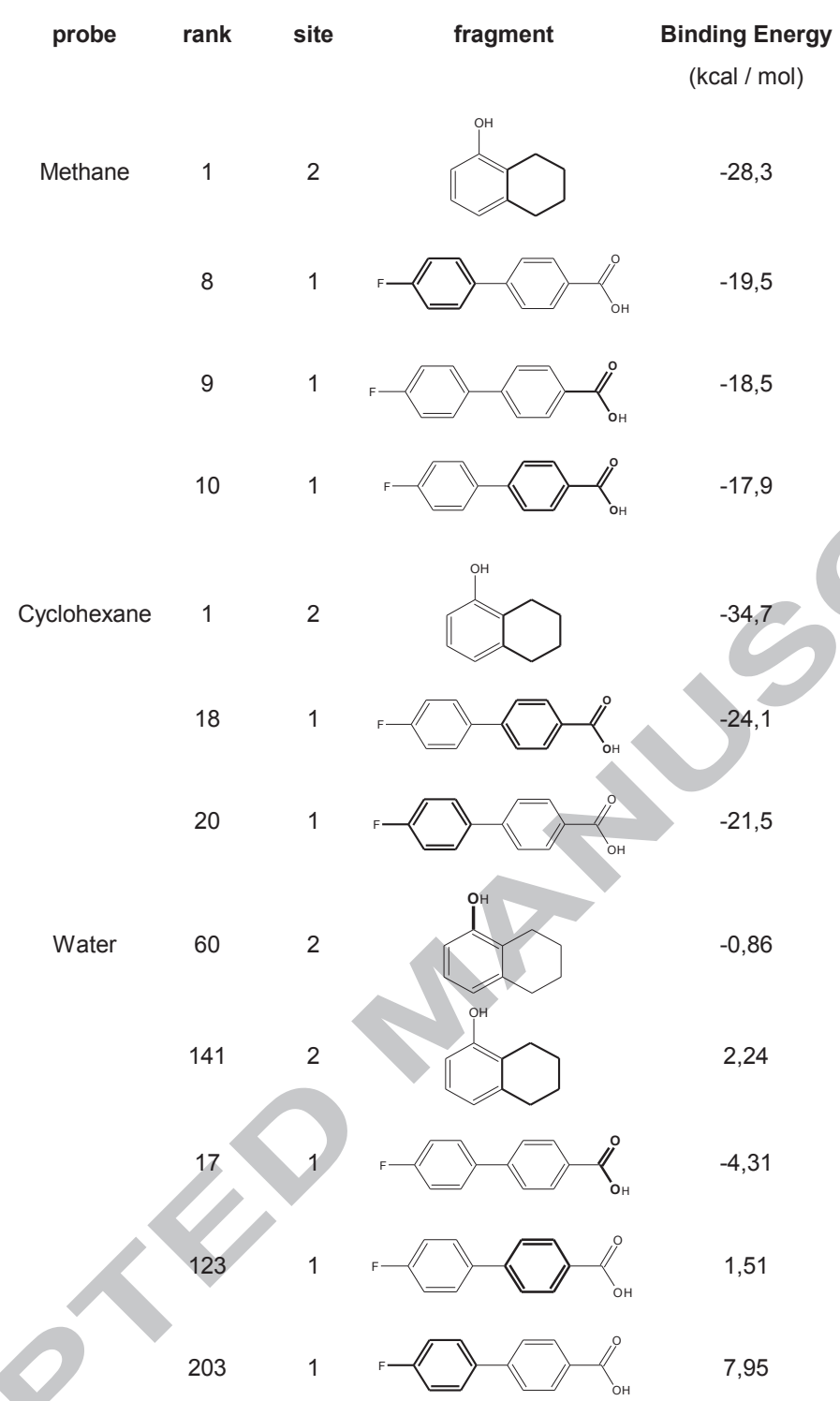

Table 1 Description of hydrophobic probes binding by MCSS. ${ }^{40}$ Bold atoms and bonds of the original co-crystallized fragments indicates probe subcavity occupancy.

Having determined two binding hot spots, the precise binding mode of small ligands remains to be solved. To this end, we used one of the most efficient scaffold among the series of Bcl$\mathrm{xL}$ inhibitors, i.e. polyphenol derivatives. Fragment deconstruction ${ }^{41,42}$ of compound 6 ref $^{43}$ deciphered the most probable binding sites for polyphenol (Fig. 6, table 2). The polyphenol (fragment A) clustered in three subregions of site 2. The first (Site 2a) is sandwiched between Asp95 and Tyr195, above Ala93. The second (site 2b) corresponds to the subcavity occupied by the cyclohexyl of crystallized tetrahydronaphtalen-1-ol, above Val141. The third (site 2c) is between the others, overhung by Glu96, Arg100 and Tyr101. Fragment B and C are centred on the latter region, suggesting it could be actually the polyphenol biding site. This region form a hinge between the hydrophobic hot spots, ideally placed to link two hydrophobic groups of ligands. 

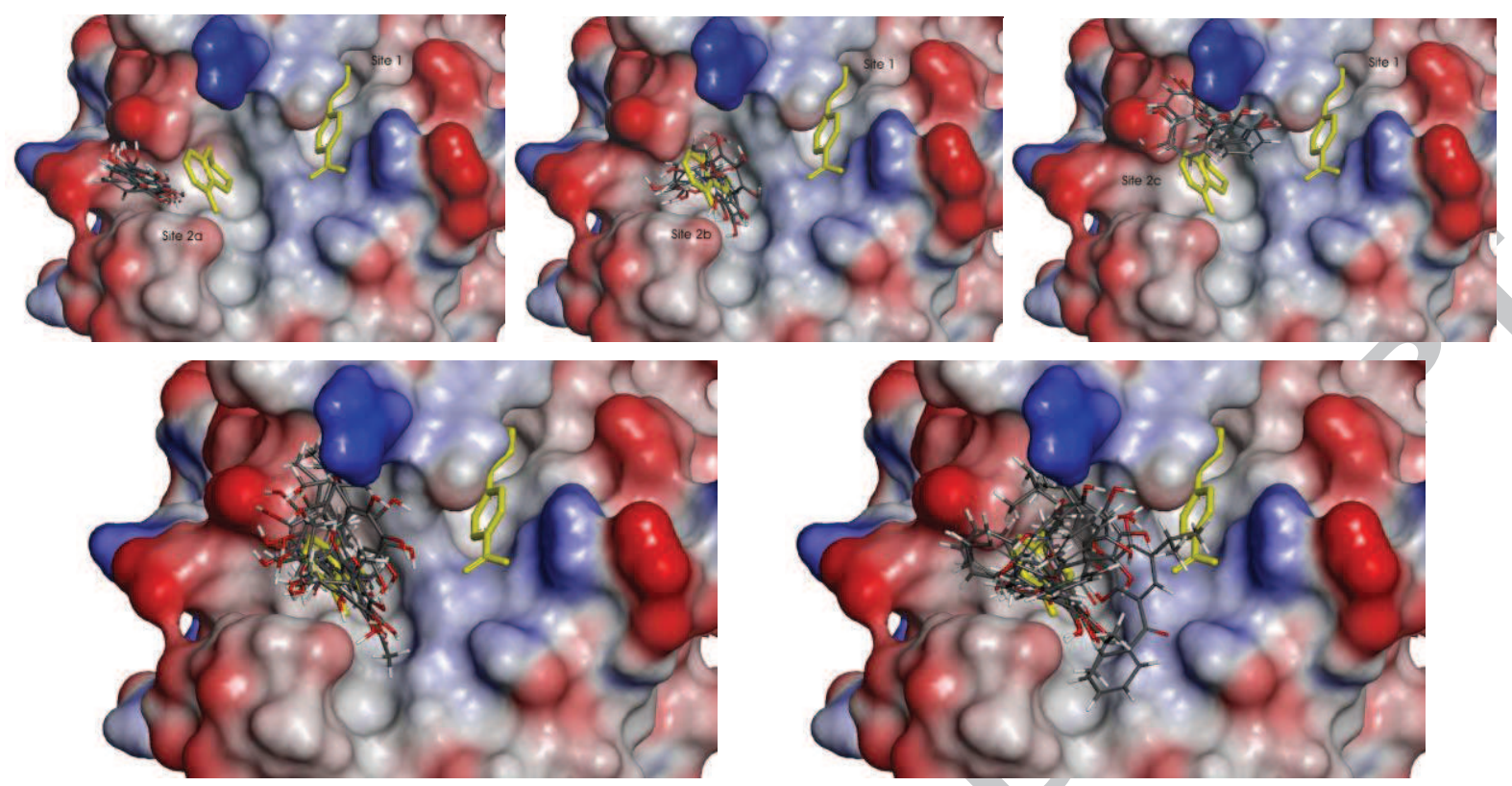

Fig. 6 Virtual fragment screening by decomposition of compound 6 ref $^{43}$ in Bcl-xL protein surface. Polyphenol fragment A clustered in three subpockets of site 2 (top, sites 2a to $2 \mathrm{c}$ from left to right). At the bottom, fragments B and C occupied the median subpocket. Co-crystallized fragments ${ }^{20}$ are in yellow.

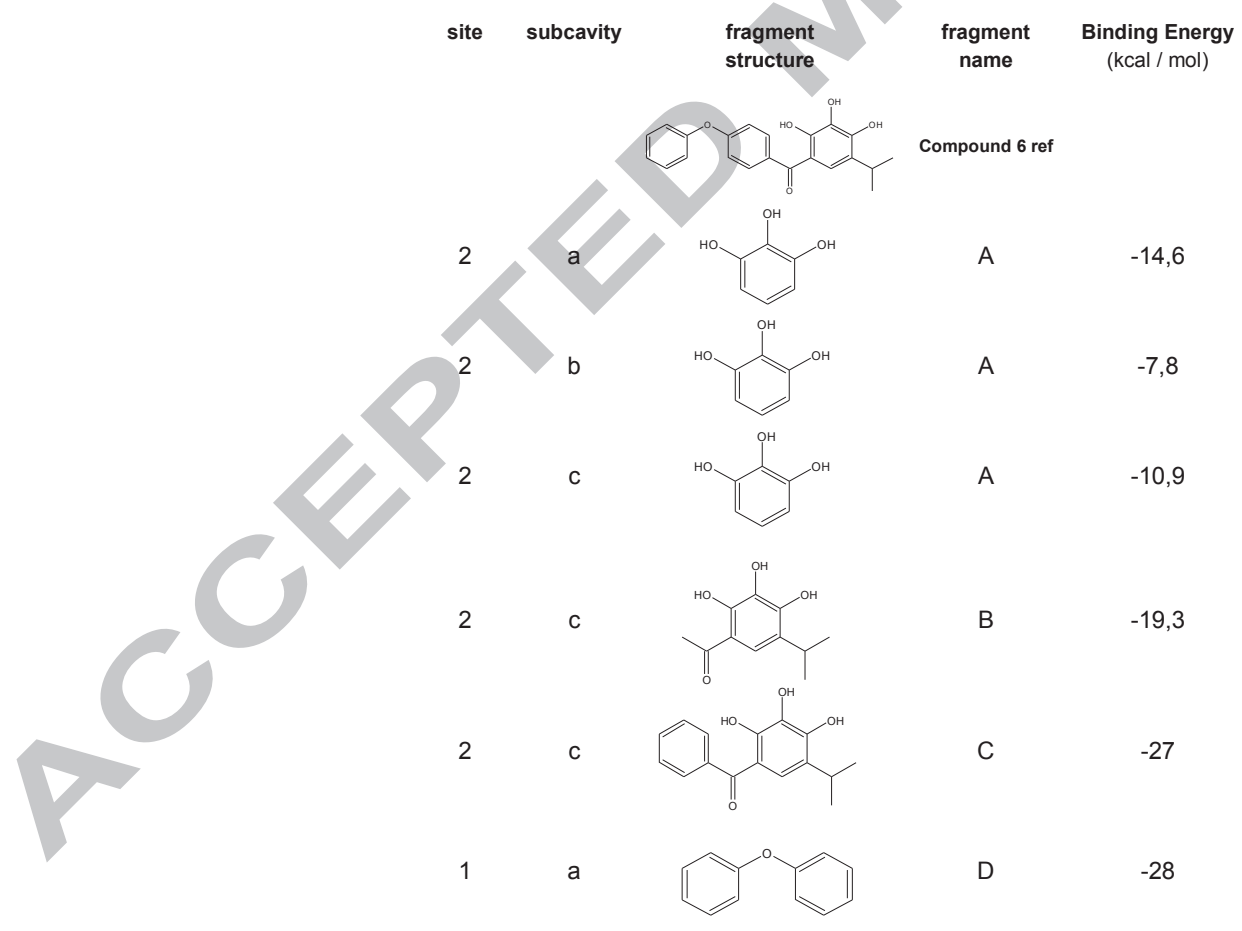

Table 2 Fragment deconstruction of compound $6 .{ }^{43}$ Binding energy was calculated after MCSS.

Accordingly, classical docking and scoring showed this region can accommodate potent inhibitors, as illustrated by TM-179, ${ }^{43}$ a bulkier analog of compound 6 ref with two large hydrophobic groups (Fig. 7). In this binding mode, the polyphenol forms HB with Glu96 and Arg100, the diphenyl ether occupies roughly the site 2, and the benzothiazole group turns onto the site 1, near Trp137. MCSS confirmed that site 2 was among the preferred crevices for diphenyl ether fragment D (table 2). 


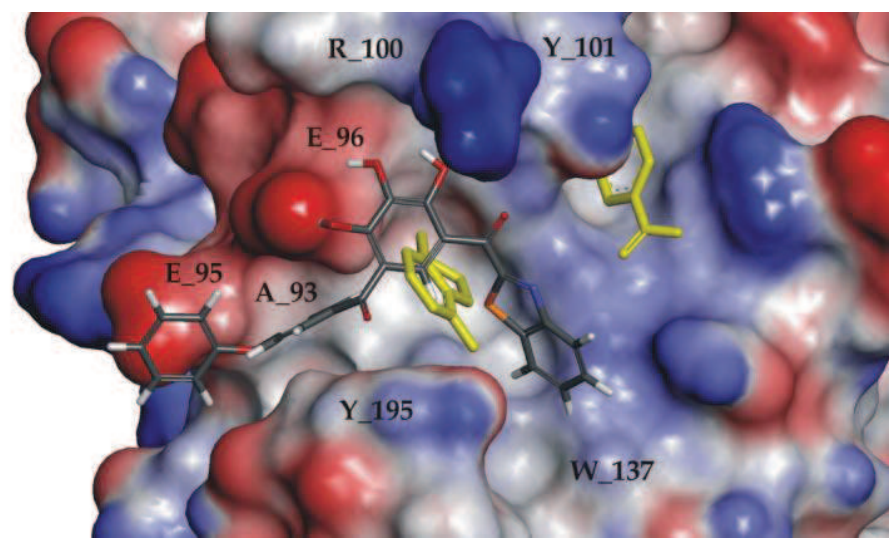

Fig. 7 Proposed binding mode of TM-179 (Fig. 2), superimposed with co-crystallized fragments in yellow.

\subsection{Testing the predicted binding mode with novel compounds: synthesis of ketone bioisosters}

Interestingly, the ketone of the benzothiazole face is well-positioned to form an HB with Tyr101, and we previously suggested that the ketone of a para-fluorobenzyl derivative of compound 6 ref form such a HB. ${ }^{44}$ The triazole series we described recently, including the mixed polyphenol-triazoles $\boldsymbol{A}$ and $\boldsymbol{B}$ (Fig. 8), conserved the HB ability. ${ }^{45}$ However, minute changes of the ligand positioning in the binding site was supposed to impair the interaction. ${ }^{46}$ So we tested in the present work bioisosteric replacements to probe subtle variations of the HB vector geometry. ${ }^{47}$ These new compounds, pyrimidine $\mathbf{1}$ and phthalazine $\mathbf{2}$ were prepared and submitted to Bioluminescence Resonance Energy Transfer (BRET) assay.

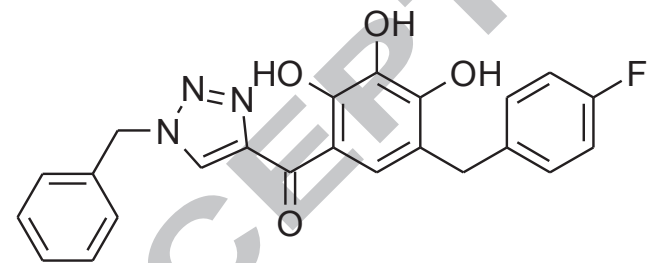

A<smiles>Oc1c(Cc2ccc(F)cc2)cc(-c2cn(-c3ccc(Oc4ccccc4)cc3)nn2)c(O)c1O</smiles>

B<smiles>Oc1c(Cc2ccc(F)cc2)cc(-c2cc(-c3ccc(Oc4ccccc4)cc3)ncn2)c(O)c1O</smiles>

1<smiles>Oc1c(Cc2ccc(F)cc2)cc(-c2nncc3cc(Oc4ccccc4)ccc23)c(O)c1O</smiles>

2

Fig. 8 Novel compounds $\mathbf{1}$ and $\mathbf{2}$ based on previous lead $\mathbf{A}$ and $\mathbf{B}$.

The synthesis of the desired pyrimidine $\mathbf{1}$ is reported in Scheme 1. Metallation by $n$-Buli of commercially available alkyne $\mathbf{3}$, followed by addition on aldehyde $4,{ }^{42}$ gave the corresponding propargylic alcohol which was immediately oxidized with IBX to afford the 
propargylic ketone 5 in $69 \%$ overall yield for the two steps. Then, condensation of $\mathbf{5}$ with amidine gave the pyrimidine 6 in $72 \%$ yield. Finally, $\mathrm{BBr}_{3}$-mediated deprotection of the methoxy ethers afforded the target pyrimidine 1 in $61 \%$ yield.<smiles>C#Cc1ccc(Oc2ccccc2)cc1</smiles>

3<smiles>COc1c(C=O)cc(Cc2ccc(F)cc2)c(OC)c1OC</smiles>

(a)<smiles>COc1cc(Cc2ccc(F)cc2)c(OC)c(OC)c1C(=O)C#Cc1ccc(Oc2ccccc2)cc1</smiles>

(c)

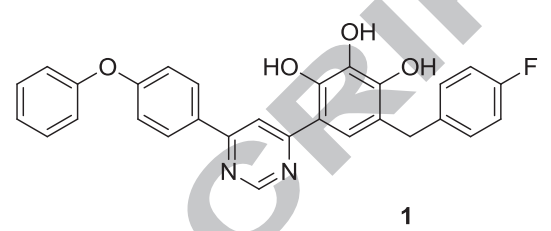

Scheme 1. reagents and conditions: (a) 1) $3, n$-BuLi, $-78^{\circ} \mathrm{C}$, then $4,-78^{\circ} \mathrm{C}-\mathrm{rt}$; 2) IBX, $69 \% 2 \mathrm{steps}$; (b) $\mathrm{HN}=\mathrm{CHNH} \mathrm{H}_{2} \cdot \mathrm{AcOH}, \mathrm{MeCN}$, reflux, $24 \mathrm{~h}$, $72 \%$; (c) $\mathrm{BBr}_{3}, \mathrm{CH}_{2} \mathrm{Cl}_{2}, 0^{\circ} \mathrm{C}$-rt, $24 \mathrm{~h}, 61 \%$.

Scheme 1 Synthesis of the mixed polyphenol-pyrimidine inhibitor 1.

The synthesis of the designed phtalazine 2 is reported in Scheme 2. Metallation of known ${ }^{47}$ bromide 7 followed by reaction with DMF gave the aldehyde 8 in 43\% yield. Then, reaction with phenol afforded the ether 9 in $81 \%$ yield. Reaction with the lithium derivative of $\mathbf{1 3},{ }^{40}$ gave the benzylic alcohol 10 (67\%) which was oxidized and deprotected to give the ketoaldehyde 11 (91\% for two steps). Condensation with hydrazine gave in $72 \%$ yield the phthalazine 12 and after deprotection of the ether groups the target molecule $\mathbf{2}$ ( $80 \%$ yield).<smiles>COc1c(Cc2ccc(F)cc2)cc(C(O)c2ccc(Oc3ccccc3)cc2C2OCCCO2)c(OC)c1OCC(C)(C)C(C)(C)C</smiles>

(d)<smiles>COc1c(Cc2ccc(F)cc2)cc(C(=O)c2ccc(Oc3ccccc3)cc2C=O)c(OC)c1OC</smiles>

11<smiles>COc1c(Cc2ccc(F)cc2)cc(-c2nncc3cc(Oc4ccccc4)ccc23)c(OC)c1OC</smiles>

12<smiles>Oc1c(Cc2ccc(F)cc2)cc(-c2nncc3cc(Oc4ccccc4)ccc23)c(O)c1O</smiles>

13<smiles>COc1c(Br)cc(Cc2ccc(F)cc2)c(OC)c1OC</smiles>

Scheme 2. reagents and conditions: (a) $n-\mathrm{BuLi} \mathrm{Et}_{2} \mathrm{O},-78^{\circ} \mathrm{C}$, then $\mathrm{DMF},-78^{\circ} \mathrm{C}-\mathrm{rt}, 43 \%$; (b) $\mathrm{PhOH}, \mathrm{K}_{2} \mathrm{CO}_{3}, \mathrm{DMF}, 110^{\circ} \mathrm{C}, 24 \mathrm{~h}, 81 \%$; $\left.\mathrm{c}\right) 13$, $t$-BuLi, $\mathrm{Et}_{2} \mathrm{O},-78^{\circ} \mathrm{C}$, then $9,-78^{\circ} \mathrm{C}-\mathrm{rt}, 67 \%$; (d) 1) IBX, 2) $\mathrm{HCl} 10 \%$ reflux, $91 \% 2$ steps; (e) $\mathrm{N}_{2} \mathrm{H}_{4} \cdot \mathrm{H}_{2} \mathrm{O}, \mathrm{EtOH}, \mathrm{reflux}, 1 \mathrm{~h}, 72 \%$; (f) $\mathrm{BBr}$, $\mathrm{CH}_{2} \mathrm{Cl}_{2}, 0^{\circ} \mathrm{C}$-rt, $24 \mathrm{~h}, 80 \%$.

Scheme 2 Synthesis of the mixed polyphenol-phthalazine inhibitor 2. 
BRET assay and immunoprecipitation support a strong interaction of the compounds with Bcl-xL (Fig. 9). The pyrimidine 1 proved to be slightly better than reference compound $\mathbf{6}$ ref while the phthalazine derivative 2 showed activity equivalent to ABT-737. Thus biological results outline the importance of a $\mathrm{HB}$ acceptor in appropriate position and confirm the predicted binding mode (Fig.10).
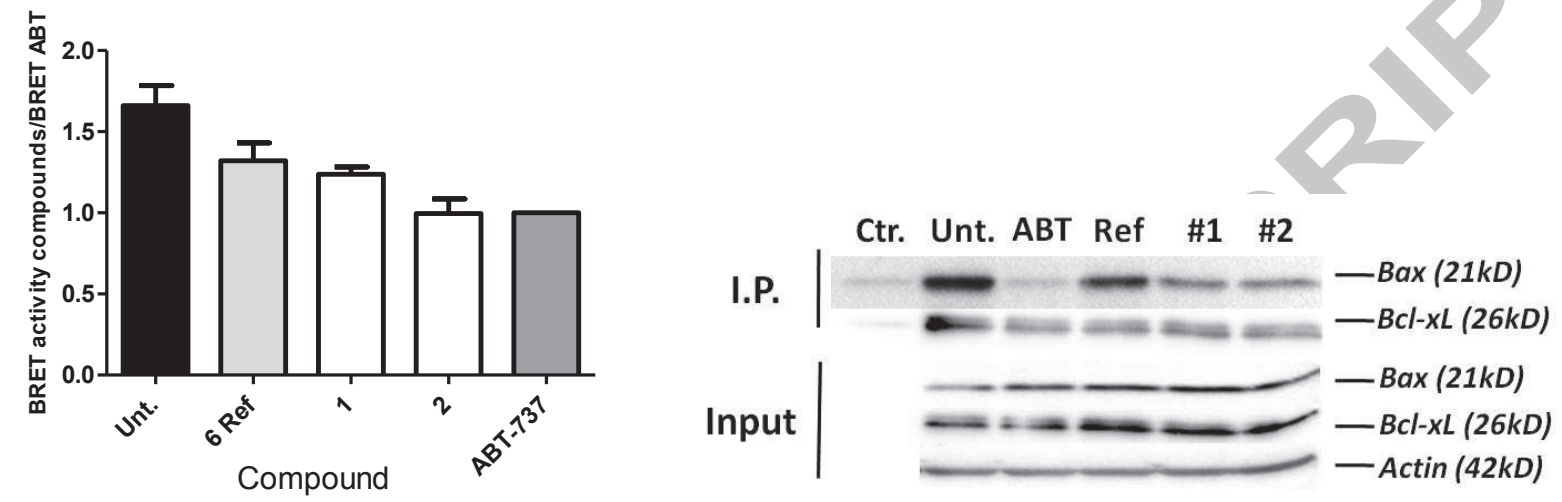

Fig. 9A (left) BRET activity of reference and novel compounds.

9B (right) Representative immunoprecipitation experiment assessing inhibition of Bax-Bcl-xL interaction by the small molecules. Protein complexes were immunoprecipitated from cell extracts with anti-Bcl-xL antibody. Anti-Bax was used in line 1, anti-Bcl-xL in line 2. A nonspecific band (actin) was used to estimate protein loading.
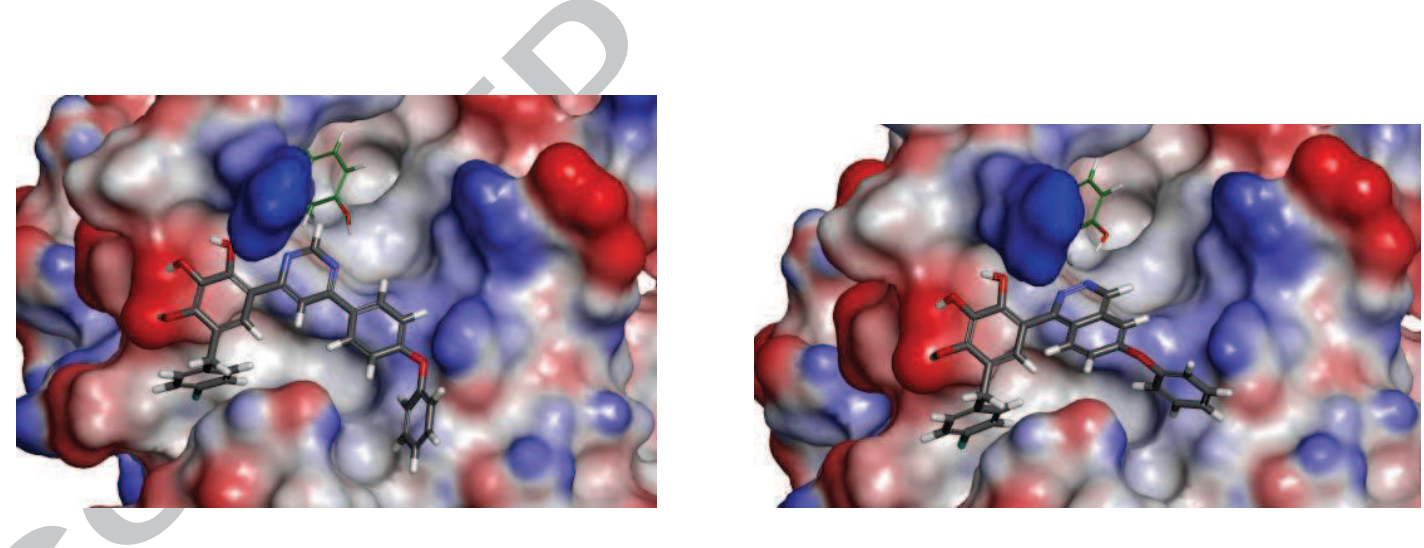

Fig. 10 Proposed binding mode of the novel aromatic bioisosters. Tyr101 forming an HB with the pyridazine and pyrimidine is detailed in thin sticks.

Finally, we paralleled our ligand-based model to the structural analyses. Manual docking of our pharmacophore in the Bcl-xL surface shows that ligand-based and structure-based models are convergent: if hydrophobic spheres of the pharmacophore occupy the site 2, HB partners can be found at the expected position: Glu96 and Arg100 for the polyphenol, Tyr195 and Arg100 / Tyr101 for the two ketones (Fig. 11). 

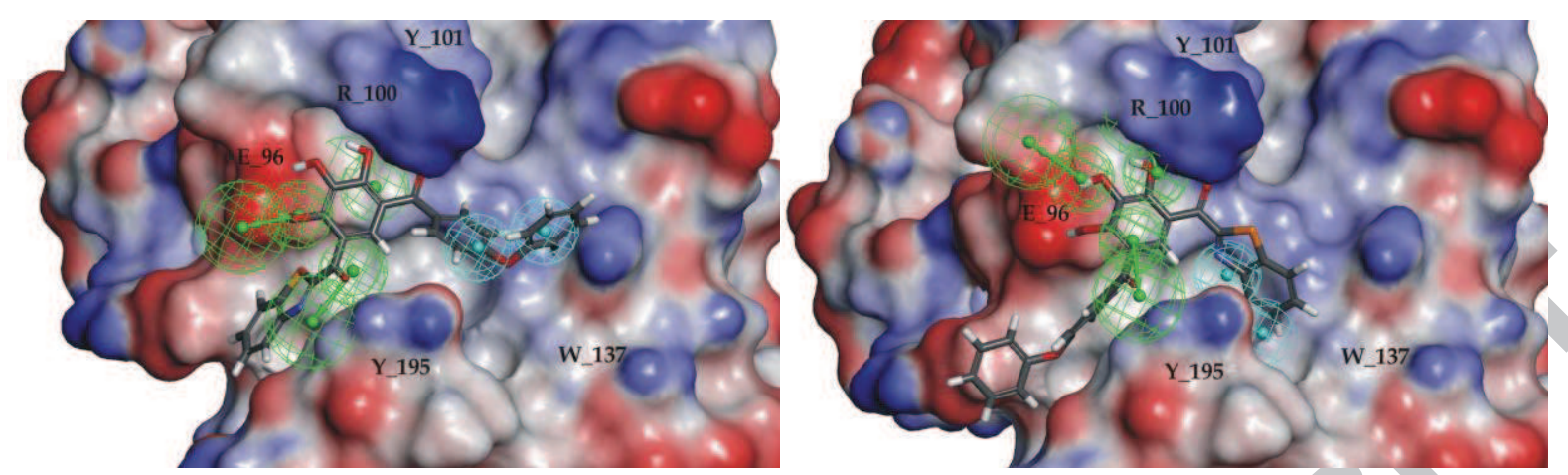

Fig. 11 Manual docking of the pharmacophore model, superimposed with two poses of TM179 obtained by classical docking, in head-to-tail orientation (left and right).

\section{Conclusion}

Prosurvival Bcl-2 family of proteins is a mainspring of cell survival and apoptosis pathways, repressing cell death by inhibiting proapoptotic effectors such as Bax, Bak or BH3-only proteins. It is consequently the subject matter of many drug discovery efforts in anticancer therapy. However, PPI is a challenging task for drug-like molecules, because of the characteristics of the protein interfaces: they are usually flat or less concave than classical drug binding sites, and have a larger surface area. ${ }^{48}$ At the periphery of proteins and solventexposed, interfaces are less subject to structural constraints, and Bcl-xL proved to be particularly flexible. ${ }^{49},{ }^{50}$ Transient pocket may also form on these surfaces. ${ }^{51}$ Structural studies with Bcl-xL have shown that PPI inhibitors bind the large crevice receiving $\mathrm{BH} 3$ peptides, acting as competitive inhibitors. ${ }^{20,52}$ They revealed also that large molecules occupy different subcavities of the crevice. Only portions of inhibitors overlap, making precise identification of small molecules binding site difficult.

If recent medicinal chemistry efforts allowed Bcl-xL PPI inhibitors affinity to increase, their size has grown simultaneously, moving them away from ideal drug candidates. To impede this evolution, we decided to go back to small efficient scaffolds, illustrated by polyphenol derivatives. Previous studies showed that polyphenols bind to the large BH3 interface, and molecular modelling with Bcl-2 suggested that they occupy a subcavity formed by Leu130, Leu108, Phe146, Phe107 and Tyr195. Polyphenols were supposed to make HB with Arg139 and Asn $136 .^{53}$

By using a combination of structural comparisons, structure-based and ligand-based molecular modelling experiments as well as structure-activity relationship analysis, the present work supports another binding site. The difference in the hypothetical binding site for polyphenol compounds results certainly from the available crystal structures, i.e. protein conformation considered. Wang et al. made their assumption based on a homology model of Bcl-2 built on Bcl-xL co-crystallized with Bim peptide. ${ }^{53,43}$ Since additional 3D structures are now available, we analyzed this experimental conformational ensemble of Bcl-xL protein, and we compared the binding modes of co-crystallized ligands. Despite that ABT-737 and more recent inhibitors occupy actually the middle of the $\mathrm{BH} 3$ binding groove, our analysis supports the possibility that smaller inhibitors have greater ligand efficiency by making use of binding hot spots. Site 1 and 2 detected by fragment crystallization are certainly these hot spots, and a hinge between them is more amenable to bind polyphenol derivatives than previously proposed pocket. This novel site still belongs to the Bak crevice, but its centroid is around $12 \AA$ away from previously suggested cavity of the paralog Bcl-2 protein.

This revised binding site will be used in further studies to explore the polyphenol chemical space, and should be useful in the design of more efficient small molecule inhibitors. 


\section{Materials and Methods}

\subsection{Pharmacophore generation}

The pharmacophore model was obtained using auto pharmacophore generation procedure implemented in Discovery Studio 4.0 (Accelrys Inc. San Diego, CA). A maximum of 6 features were allowed, with a minimum interfeature distance of $2 \AA$. Among the 20 hypotheses generated, we selected the model permitting the best consensus between number of matching features and fitting value. A ligand pharmacophore mapping with flexible fitting method was used thereafter to refine ligands superimposition, each molecule conformation being considered separately.

\subsection{MCSS and binding energy calculation}

Multiple Copy Simultaneous Search $(\mathrm{MCSS})^{40}$ was carried out twice, with a concentric search for the binding sites and an increasing precision. First, the procedure was driven on the entire protein surface of PDB: 1 YSG. ${ }^{20}$ The explored 'binding sites' encompassed all the protein structure, with a sphere radius of $27 \AA$. 1000 fragment replicas were initially placed in the receptor cavities, and poses were optimized by 10000 steps of Powel minimization, following 8000 steps of steepest descent, using CHARMm force-field.

Binding free energy was calculated using a molecular mechanics Poisson-Boltzmann with a non polar surface area implicit solvent model (MM-PBSA), as described with MM-GBSA. ${ }^{54}$ Cyclohexane probes clustered in different subregions of the protein surface, with a wide range of binding energy (BE of -14.2 to $31.3 \mathrm{kcal} / \mathrm{mol}$ ). The first 3 poses of cyclohexane probe occupied the site 2. Due to its smaller size, methane probe occupied more diffuse and discrete clefts (BE from -13.4 to $18.6 \mathrm{kcal} / \mathrm{mol})$. The third poses occupied site $1(\mathrm{BE}=-11.6$ $\mathrm{kcal} / \mathrm{mol}$ ). Water probe was also diffuse (BE from -11.2 to $15.1 \mathrm{kcal} / \mathrm{mol}$ ). The $123^{\text {rd }}$ pose occupied site $1(\mathrm{BE}=1.5 \mathrm{kcal} / \mathrm{mol})$, as well as the 160 th pose $(\mathrm{BE}=3.88 \mathrm{kcal} / \mathrm{mol})$. The former corresponds to the crystallized fragment fluorophenyl subpocket, the later to the benzoic acid part. The $141^{\text {st }}$ pose occupied site $2(\mathrm{BE}=2.3 \mathrm{kcal} / \mathrm{mol})$.

Due to the cyclohexyl clustering, a second MCSS step was performed. This step focused on a region including site 1 and site 2 (sphere radius of $13 \AA$ ), allowing more detailed proteinprobes interaction analysis. This refinement procedure produced results given in Table 1 and 2 .

\subsection{Classical Docking}

Docking experiments from crystal structure (PDB:1YSG) were performed using LigandFit, implemented in Discovery Studio v.4.0. A CFF energy grid was defined with $10 \AA$ extension from the binding site of $1134 \AA^{3}$, and an energetic penalty of $150 \mathrm{kcal} / \mathrm{mol} /$ atom was set outside the binding site. A softened potential energy was used, with distance dependant dielectric constant of 1 .

Ligands conformers were generated before docking experiments by using both "fast" and "best" protocols, i.e. discretized rotations about the rotatable bonds with $120^{\circ}$ search increments between sp3 atoms, with and without energy minimization steps.

After docking, each pose and binding site (ligand-receptor complex) were optimized through energy minimization (6000 steps of steepest descent with CHARMm force field). 


\subsection{Chemical syntheses}

\subsection{1 preparation of 1-(5-(4-fluorobenzyl)-2,3,4-trimethoxyphenyl)-3-(4- phenoxyphenyl)prop-2-yn-1-one (5)}

- first step: to a solution of propargyl derivative $3(411 \mathrm{mg}, 2.12 \mathrm{mmol})$ in THF (10 $\mathrm{ml})$ at $-78^{\circ} \mathrm{C}$ under argon, was added dropwise $n$-BuLi (1.65 ml, 1.25 eq., $1.6 \mathrm{M}$ in pentane). The mixture was stirred for 30 minutes. Then, a solution of aldehyde 4 (608 mg, 1 eq.) in THF $(3 \mathrm{ml})$ was added, at $-78^{\circ} \mathrm{C}$, to this organolithium derivative. The reaction mixture was allowed to warm up slowly to $\mathrm{rt}$ and it was stirred overnight and then quenched with a saturated ammonium chloride solution. The mixture was extracted with $\mathrm{Et}_{2} \mathrm{O}$. The combined organic layers were dried over $\mathrm{MgSO}_{4}$ and concentrated under reduced pressure to give the crude product that was used as such for the next step.

- second step: a solution of previous alcohol crude product $(<2.12 \mathrm{mmol})$, IBX $(890$ $\mathrm{mg}, 1.5$ eq.) in a $4 / 1$ mixture of THF/DMSO (25 ml) was heated under reflux for 20 minutes. After cooling down to rt, the reaction mixture was poured into water and filtered on celite. The solution was then extracted with $\mathrm{Et}_{2} \mathrm{O}$, washed with water and brine. The combined organic layer was dried over $\mathrm{MgSO}_{4}$ and concentrated under reduced pressure. The crude product was purified on a silica gel column using a 7/3 mixture of pentane/ether as eluent to afford 5 (705 mg, 69\%, 2 steps) as an orange solid.

${ }^{1} \mathrm{H}$ NMR $\left(300 \mathrm{MHz}, \mathrm{CDCl}_{3}\right) \square(\mathrm{ppm}): 7.57(\mathrm{~s}, 1 \mathrm{H}), 7.53(\mathrm{~d}, J=8.8 \mathrm{~Hz}, 2 \mathrm{H}), 7.22-7.14(\mathrm{~m}$, 3H), 7.09-7.04 (m, 2H), 7.01-6.93 (m, 4H), $4.00(\mathrm{~s}, 3 \mathrm{H}), 3.92(\mathrm{~s}, 2 \mathrm{H}), 3.90(\mathrm{~s}, 3 \mathrm{H}), 3.85(\mathrm{~s}$, $3 \mathrm{H}) .{ }^{13} \mathrm{C}$ NMR (75 MHz, $\left.\mathrm{CDCl}_{3}\right) \square(\mathrm{ppm}): 175.6,161.4(\mathrm{~d}, J=244.2 \mathrm{~Hz}), 159.9,156.7$, $155.5,154.2,146.4,136.0$ (d, $J=3.2 \mathrm{~Hz}), 134.9,130.3$ (d, $J=7.8 \mathrm{~Hz}), 130.0,127.3,126.8$, $124.5,120.0,118.0,115.2(\mathrm{~d}, J=21.2 \mathrm{~Hz}), 114.5,91.6,89.2,61.8,60.9,60.8,35.3 .{ }^{19} \mathrm{~F}$ NMR $\left(282.4 \mathrm{MHz}, \mathrm{CDCl}_{3}\right) \square \square \mathrm{ppm} \quad \square \mathrm{N} \square . \square \square \square\left(\mathrm{ESI}^{+}\right): \mathrm{C}_{31} \mathrm{H}_{25} \mathrm{FO}_{5} \mathrm{Na}[\mathrm{M}+\mathrm{Na}]^{+} \mathrm{m} / z$; calc: 519.1584, found: 519.1590 .

\subsection{2 preparation of 4-(5-(4-fluorobenzyl)-2,3,4-trimethoxyphenyl)-6-(4- phenoxyphenyl)pyrimidine (6)}

To a solution of propargylic ketone $5(200 \mathrm{mg}, 0.3 \mathrm{mmol})$ in $\mathrm{CH}_{3} \mathrm{CN}(15 \mathrm{ml})$ were added sodium carbonate (513 mg, 12 eq.) and formamidine acetate $(378 \mathrm{mg}, 6$ eq.). The solution was stirred under reflux overnight. After cooling down to rt, the mixture was filtered and concentrated in vacuo. The product was purified on a silica gel column with a $8 / 2$ mixture of pentane/AcOEt as eluent to afford pyrimidine $6(157 \mathrm{mg}, 72 \%)$ as a yellow viscous oil. ${ }^{1} \mathrm{H}$ NMR (300 MHz, $\left.\mathrm{CDCl}_{3}\right) \square(\mathrm{ppm}): 9.27(\mathrm{~d}, J=1.5 \mathrm{~Hz}, 1 \mathrm{H}), 8.29(\mathrm{~d}, J=1.5 \mathrm{~Hz}, 1 \mathrm{H}), 8.12$ (d, $J=8.7 \mathrm{~Hz}, 2 \mathrm{H}), 7.58(\mathrm{~s}, 1 \mathrm{H}), 7.40(\mathrm{dd}, J=7.5, J=8.4 \mathrm{~Hz}, 2 \mathrm{H}), 7.23-7.08(\mathrm{~m}, 8 \mathrm{H}), 6.96(\mathrm{t}, J$ $=8.9 \mathrm{~Hz}, 2 \mathrm{H}), 3.97(\mathrm{~s}, 3 \mathrm{H}), 3.96(\mathrm{~s}, 2 \mathrm{H}), 3.84(\mathrm{~s}, 3 \mathrm{H}), 3.79(\mathrm{~s}, 3 \mathrm{H}) .{ }^{13} \mathrm{C}$ NMR $(75 \mathrm{MHz}$, $\left.\mathrm{CDCl}_{3}\right) \square(\mathrm{ppm}): 163.1,162.8,161.3(\mathrm{~d}, J=243.7 \mathrm{~Hz}), 160.0,158.8,156.1,153.9,151.9$, $146.6,136.5$ (d, $J=3.2 \mathrm{~Hz}), 131.6,130.7,130.1$ (d, $J=7.8 \mathrm{~Hz}), 129.9,128.8,126.5,126.0$, 124.0, 119.6, 118.4, 116.3, $115.0(\mathrm{~d}, J=21.2 \mathrm{~Hz}), 61.4,60.8,60.7,35.5 .{ }^{19} \mathrm{~F}$ NMR $(282.4$ $\left.\mathrm{MHz}, \mathrm{CDCl}_{3}\right) \square \square \mathrm{ppm} \square \square \square \square \square \square \square \square\left(\mathrm{ESI}^{+}\right): \mathrm{C}_{32} \mathrm{H}_{28} \mathrm{FN}_{2} \mathrm{O}_{4}[\mathrm{M}+\mathrm{H}]^{+} \mathrm{m} / z$; calc: 523.2033, found: 523.2031 .

\subsection{3 preparation of 4-(4-fluorobenzyl)-6-(6-(4-phenoxyphenyl)pyrimidin-4- yl)benzene-1,2,3-triol (1)}


To a stirred solution of compound $6(157 \mathrm{mg}, 0.3 \mathrm{mmol})$ was added dropwise $\mathrm{BBr}_{3}(3 \mathrm{ml}, 10$ eq., $1 \mathrm{M}$ in $\left.\mathrm{CH}_{2} \mathrm{Cl}_{2}\right)$ in $\mathrm{CH}_{2} \mathrm{Cl}_{2}(5 \mathrm{ml})$ at $-78^{\circ} \mathrm{C}$ under nitrogen. The reaction mixture was allowed to warm up to $\mathrm{rt}$ and stirred overnight. The mixture was quenched with $\mathrm{MeOH}$. After evaporation of the solvent to dryness, the residue was recrystallized from $\mathrm{CHCl}_{3}$ to afford 1 (88 $\mathrm{mg}, 61 \%)$ as an orange solid. Mp: $205-207^{\circ} \mathrm{C} .{ }^{1} \mathrm{H}$ NMR $\left(300 \mathrm{MHz}, \mathrm{DMSO} \mathrm{d}_{6}\right) \delta(\mathrm{ppm})$ : 13.92 (br s, 1H), 9.29 (br s, 1H), 9.12 (s, 1H), 8.82 (br s, 1H), 8.51 (s, 1H), 8.38 (d, $J=8.9$ $\mathrm{Hz}, 2 \mathrm{H}), 7.84(\mathrm{~s}, 1 \mathrm{H}), 7.46(\mathrm{dd}, J=7.6,8.3 \mathrm{~Hz}, 2 \mathrm{H}), 7.28(\mathrm{dd}, J=5.7,8.6 \mathrm{~Hz}, 2 \mathrm{H}), 7.22(\mathrm{tt}, J$ $=1.1,7.4 \mathrm{~Hz}, 2 \mathrm{H}), 7.16-7.11(\mathrm{~m}, 4 \mathrm{H}), 7.05(\mathrm{t}, J=8.9 \mathrm{~Hz}, 2 \mathrm{H}), 3.89(\mathrm{~s}, 2 \mathrm{H}) .{ }^{13} \mathrm{C} \mathrm{NMR}(75$ MHz, DMSO d $\left.\mathrm{d}_{6}\right) \delta(\mathrm{ppm}): 164.6,160.5(\mathrm{~d}, J=244.0 \mathrm{~Hz}), 160.4,159.7,158.8,156.0,155.6$, 149.2, 148.2, 137.7 (d, $J=3.2 \mathrm{~Hz}), 132.9,130.9,130.2,130.0(\mathrm{~d}, J=7.8 \mathrm{~Hz}), 129.4,124.3$, 119.7, 118.0, $114.6(\mathrm{~d}, J=21.2 \mathrm{~Hz}), 109.6,108.6,34.6 .{ }^{19} \mathrm{~F}$ NMR $\left(282.4 \mathrm{MHz}, \mathrm{DMSO}_{6}\right) \delta$ (ppm): -118.0. HRMS (ESI $\left.{ }^{+}\right): \mathrm{C}_{29} \mathrm{H}_{21} \mathrm{FN}_{2} \mathrm{O}_{4} \mathrm{Na}[\mathrm{M}+\mathrm{Na}]^{+} m / z$; calc: 454.9270, found: 454.9268 .

\subsection{4 preparation of 2-(1,3-dioxan-2-yl)-4-fluorobenzaldehyde (8)}

To a solution of $7(510 \mathrm{mg}, 2 \mathrm{mmol})$ in $\mathrm{Et}_{2} \mathrm{O}(10 \mathrm{ml})$ was added dropwise under argon, $n$ $\operatorname{BuLi}\left(1.56 \mathrm{ml}, 1.25\right.$ eq.) at $-78^{\circ} \mathrm{C}$. The mixture was stirred for 30 minutes at $-78^{\circ} \mathrm{C}$ before addition of DMF $(0.3 \mathrm{ml}, 2$ eq.). The reaction mixture was allowed to warm up to $\mathrm{rt}$ and stirred for $4 \mathrm{~h}$ and then quenched with a saturated ammonium chloride solution and extracted with $\mathrm{Et}_{2} \mathrm{O}$. The combined organic layers were dried over $\mathrm{MgSO}_{4}$ and concentrated under reduced pressure. The crude product was purified by flash column chromatography using a $7 / 3$ mixture of pentane/ $\mathrm{Et}_{2} \mathrm{O}$ as eluent to afford aldehyde $\mathbf{8}(174.6 \mathrm{mg}, 43 \%)$ as a colorless oil. ${ }^{1} \mathrm{H}$ NMR (300 MHz, Acetone $\left.\mathrm{D}_{6}\right) \delta(\mathrm{ppm}): 10.30$ (s, 1H), 7.98 (dd, J= 5.7, 8.4 Hz, 1H), 7.44 $(\mathrm{dd}, J=2.4,9.6 \mathrm{~Hz}, 1 \mathrm{H}), 7.34-7.28(\mathrm{~m}, 1 \mathrm{H}), 6.13(\mathrm{~s}, 1 \mathrm{H}), 4.27-4.21(\mathrm{~m}, 2 \mathrm{H}), 4.14-4.05(\mathrm{~m}$, 2H), 2.24-2.05 (m, 1H), 1.57-1.48 (m, 1H). $\left.{ }^{13} \mathrm{C} \mathrm{NMR} \mathrm{(100} \mathrm{MHz,} \mathrm{Acetone} \mathrm{D}_{6}\right) \delta(\mathrm{ppm}): 191.8$, $167.3(\mathrm{~d}, J=252.9 \mathrm{~Hz}), 145.6(\mathrm{~d}, J=8.7 \mathrm{~Hz}), 133.4(\mathrm{~d}, J=9.6 \mathrm{~Hz}), 117.7(\mathrm{~d}, J=22.0 \mathrm{~Hz})$, $115.9(\mathrm{~d}, J=23.9 \mathrm{~Hz}), 100.3(\mathrm{~d}, J=1.6 \mathrm{~Hz}), 69.2,27.5 .{ }^{19} \mathrm{~F}$ NMR $\left(282.4 \mathrm{MHz}, \mathrm{CDCl}_{3}\right) \delta$ (ppm): -106.2. $\mathrm{HRMS}\left(\mathrm{ESI}^{+}\right): \mathrm{C}_{11} \mathrm{H}_{11} \mathrm{FO}_{3} \mathrm{Na}[\mathrm{M}+\mathrm{Na}]^{+} \mathrm{m} / z$; calc: 233.0590 , found: 233.0591 .

\subsection{5 preparation of 2-(1,3-dioxan-2-yl)-4-phenoxybenzaldehyde (9)}

A solution of aldehyde 8 (157.6 mg, $0.77 \mathrm{mmol})$, phenol (75.9 mg, 1.05 eq.) and $\mathrm{K}_{2} \mathrm{CO}_{3}$ (212.5 mg, 2 eq.) in DMF ( $5 \mathrm{ml})$ was heated at $110^{\circ} \mathrm{C}$ overnight. After cooling down to rt, water was added. The mixture was extracted with $\mathrm{Et}_{2} \mathrm{O}$, washed 2-3 times with water and brine. The combined organic layers were dried over $\mathrm{MgSO}_{4}$ and concentrated under reduced pressure. The crude product was purified by flash column chromatography using a $7 / 3$ mixture of pentane/ $\mathrm{Et}_{2} \mathrm{O}$ as eluent to afford the desired product $9(173.4 \mathrm{mg}, 81 \%)$ as a colorless oil. ${ }^{1} \mathrm{H}$ NMR $\left(300 \mathrm{MHz}, \mathrm{CDCl}_{3}\right) \delta(\mathrm{ppm}): 10.37(\mathrm{~s}, 1 \mathrm{H}), 7.89(\mathrm{~d}, J=8.7 \mathrm{~Hz}, 1 \mathrm{H})$, $7.40(\mathrm{t}, J=7.6 \mathrm{~Hz}, 2 \mathrm{H}), 7.30(\mathrm{~d}, J=2.4 \mathrm{~Hz}, 1 \mathrm{H}), 7.21(\mathrm{td}, J=1.1,7.4 \mathrm{~Hz}, 1 \mathrm{H}), 7.06(\mathrm{~d}, J=$ $7.8 \mathrm{~Hz}, 1 \mathrm{H}), 6.98(\mathrm{dd}, J=2.4,8.7 \mathrm{~Hz}, 1 \mathrm{H}), 6.00(\mathrm{~s}, 1 \mathrm{H}), 4.30-4.24(\mathrm{~m}, 2 \mathrm{H}), 4.02-3.97$ (m, $2 \mathrm{H}), 2.28-2.18(\mathrm{~m}, 1 \mathrm{H}), 1.49-1.43(\mathrm{~m}, 1 \mathrm{H}) .{ }^{13} \mathrm{C} \mathrm{NMR}\left(75 \mathrm{MHz}, \mathrm{CDCl}_{3}\right) \delta(\mathrm{ppm}): 190.7$, $162.3,155.1,142.2,132.6,130.1,128.4,124.7,120.3,111.4,116.2,93.3,67.6,25.6$. HRMS $\left(\mathrm{ESI}^{+}\right): \mathrm{C}_{17} \mathrm{H}_{16} \mathrm{O}_{4} \mathrm{Na}[\mathrm{M}+\mathrm{Na}]^{+} \mathrm{m} / z$; calc: 307.0946 , found: 307.0940 .

\subsection{6 preparation of (2-(1,3-dioxan-2-yl)-4-phenoxyphenyl)(5-(4-fluorobenzyl)- 2,3,4-trimethoxyphenyl)methanol (10)}


To a solution of bromo derivative $13,{ }^{47}(230 \mathrm{mg}, 0.65 \mathrm{mmol})$ in $\mathrm{Et}_{2} \mathrm{O}(5 \mathrm{ml})$ was added dropwise under argon, $t$-BuLi $(0.89 \mathrm{ml}, 2.2$ eq. $)$ at $-78^{\circ} \mathrm{C}$. The mixture was stirred for 30 minutes at $-78^{\circ} \mathrm{C}$ before addition of a solution of aldehyde 9 (150 mg, 0.83 eq.) in $\mathrm{Et}_{2} \mathrm{O}(2$ $\mathrm{ml}$ ). The reaction mixture was allowed to warm up to $\mathrm{rt}$ and stirred overnight and then quenched with a saturated ammonium chloride solution and extracted with ethyl acetate. The combined organic layers were dried over $\mathrm{MgSO}_{4}$ and concentrated under reduced pressure. The crude product was purified by flash column chromatography using a 7/3 mixture of pentane/EA as eluent to afford the alcohol $10(199 \mathrm{mg}, 67 \%)$ as a colorless viscous oil. ${ }^{1} \mathrm{H}$ NMR (300 MHz, Acetone $\left.\mathrm{D}_{6}\right) \delta(\mathrm{ppm}): 7.41-7.33(\mathrm{~m}, 3 \mathrm{H}), 7.28-7.21(\mathrm{~m}, 3 \mathrm{H}), 7.12(\mathrm{tt}, J=$ 1.1, $7.4 \mathrm{~Hz}, 1 \mathrm{H}), 7.10(\mathrm{~s}, 1 \mathrm{H}), 7.02(\mathrm{t}, J=8.9 \mathrm{~Hz}, 2 \mathrm{H}), 6.99-6.96(\mathrm{~m}, 2 \mathrm{H}), 6.93(\mathrm{dd}, J=2.7$, $8.5 \mathrm{~Hz}, 1 \mathrm{H}), 6.33$ (d, $J=4.3 \mathrm{~Hz}, 1 \mathrm{H}), 5.76(\mathrm{~s}, 1 \mathrm{H}), 4.40$ (d, $J=4.4 \mathrm{~Hz}, 1 \mathrm{H}), 4.17-3.79$ (m, $4 \mathrm{H}), 3.92(\mathrm{~s}, 2 \mathrm{H}), 3.84(\mathrm{~s}, 3 \mathrm{H}), 3.73(\mathrm{~s}, 3 \mathrm{H}), 3.62(\mathrm{~s}, 3 \mathrm{H}), 2.12-1.98(\mathrm{~m}, 1 \mathrm{H}), 1.44-1.36(\mathrm{~m}$, $1 \mathrm{H}) .{ }^{13} \mathrm{C}$ NMR $\left(75 \mathrm{MHz}\right.$, Acetone $\left.\mathrm{D}_{6}\right) \delta(\mathrm{ppm}): 163.1(\mathrm{~d}, J=241.7 \mathrm{~Hz}), 159.4,157.7,152.8$, $151.5,148.0,140.0,139.7,139.5(\mathrm{~d}, J=3.3 \mathrm{~Hz}), 134.6,132.2(\mathrm{~d}, J=7.9 \mathrm{~Hz}), 131.7,131.1$, $130.8,125.2,125.0,120.4,118.3,116.6$ (d, $J=21.3 \mathrm{~Hz}), 100.4,69.0,68.9,67.6,61.9,61.8$, 61.7, 36.8, 27.5. ${ }^{19} \mathrm{~F}$ NMR $\left(282.4 \mathrm{MHz}\right.$, Acetone $\left.\mathrm{D}_{6}\right) \delta(\mathrm{ppm}):-11 \square \square \mathrm{HRMS}\left(\mathrm{ESI}^{+}\right)$: $\mathrm{C}_{33} \mathrm{H}_{33} \mathrm{FO}_{7} \mathrm{Na}[\mathrm{M}+\mathrm{Na}]^{+} \mathrm{m} / z$; calc: 583.2108 , found: 583.2105 .

\subsection{7 preparation of 2-(5-(4-fluorobenzyl)-2,3,4-trimethoxybenzoyl)-5- phenoxybenzaldehyde (11)}

First, a solution of previous alcohol 10 (187 mg, $0.33 \mathrm{mmol})$, IBX (140.2 mg, 1.5 eq.) in a 4/1 mixture of THF/DMSO (5 ml) was heated under reflux for 20 minutes. After cooling down to $\mathrm{rt}$, the mixture was poured into water and filtered on celite. The solution was then extracted with $\mathrm{Et}_{2} \mathrm{O}$, washed with water and brine. The combined organic layer was dried over $\mathrm{MgSO}_{4}$ and concentrated under reduced pressure. This crude product (pure by NMR) was used directly for next step. Then, to a solution of this ketone $(<0.33 \mathrm{mmol}), 10 \% \mathrm{HCl}(0.44 \mathrm{ml})$ in a $2 / 1$ mixture of $\mathrm{THF} / \mathrm{H}_{2} \mathrm{O}(9 \mathrm{ml})$, was heated at $80^{\circ} \mathrm{C}$ overnight. After cooling down to $\mathrm{rt}$, the solution was neutralized with a saturated sodium bicarbonate solution and extracted with $\mathrm{Et}_{2} \mathrm{O}$. The combined organic layers were dried over $\mathrm{MgSO}_{4}$ and concentrated under reduced pressure. The residue was purified on a silica gel column using the mixture pentane/ether $7 / 3$ as eluent to give 11 (151.3 mg, 91\%, 2 steps) as a light yellow viscous oil. ${ }^{1} \mathrm{H}$ NMR (300 $\left.\mathrm{MHz}, \mathrm{CDCl}_{3}\right) \delta(\mathrm{ppm}): 10.18(\mathrm{~s}, 1 \mathrm{H}), 7.51(\mathrm{~d}, J=2.6 \mathrm{~Hz}, 1 \mathrm{H}), 7.46(\mathrm{~d}, J=8.5 \mathrm{~Hz}, 1 \mathrm{H}), 7.41$ $(\mathrm{dd}, J=7.5,8.4 \mathrm{~Hz}, 2 \mathrm{H}), 7.22(\mathrm{tt}, J=1.1,7.4 \mathrm{~Hz}, 2 \mathrm{H}), 7.18-7.13(\mathrm{~m}, 4 \mathrm{H}), 7.09-7.05(\mathrm{~m}, 2 \mathrm{H})$, $6.96(\mathrm{t}, J=8.7 \mathrm{~Hz}, 2 \mathrm{H}), 3.90(\mathrm{~s}, 2 \mathrm{H}), 3.85(\mathrm{~s}, 3 \mathrm{H}), 3.81(\mathrm{~s}, 3 \mathrm{H}), 3.63(\mathrm{~s}, 3 \mathrm{H}) .{ }^{13} \mathrm{C}$ NMR $(75$ $\left.\mathrm{MHz}, \mathrm{CDCl}_{3}\right) \delta(\mathrm{ppm}): 194.2,190.8,161.4(\mathrm{~d}, J=244.1 \mathrm{~Hz}), 160.2,159.8,155.9,155.2$, $152.6,146.2,138.3,137.1,136.0(\mathrm{~d}, J=3.2 \mathrm{~Hz}), 131.9,130.3,130.2,130.1(\mathrm{~d}, J=7.8 \mathrm{~Hz})$, $127.9,126.2,124.9,121.2,120.0,116.7,115.2(\mathrm{~d}, J=21.2 \mathrm{~Hz}), 61.4,60.7,35.3 .{ }^{19} \mathrm{~F}$ NMR $\left(282.4 \mathrm{MHz}, \mathrm{CDCl}_{3}\right) \delta(\mathrm{ppm}):-11 \square 1$. HRMS $\left(\mathrm{ESI}^{+}\right): \mathrm{C}_{30} \mathrm{H}_{25} \mathrm{FO}_{6} \mathrm{Na}[\mathrm{M}+\mathrm{Na}]^{+} \mathrm{m} / z$; calc: 523.1533, found: 523.1533 .

\subsection{8 preparation of 1-(5-(4-fluorobenzyl)-2,3,4-trimethoxyphenyl)-6- phenoxyphthalazine (12)}

To a solution of $11(116 \mathrm{mg}, 0.23 \mathrm{mmol})$ in EtOH $(5 \mathrm{ml})$ at $\mathrm{rt}$, was added $\mathrm{N}_{2} \mathrm{H}_{4} \cdot \mathrm{H}_{2} \mathrm{O}(56 \mu \mathrm{l}, 5$ eq.). The mixture was stirred under reflux for $1 \mathrm{~h}$ and it was concentrated in vacuo. The crude product was purified on a silica gel column using a 1/1 mixture of pentane/EA as eluent to afford phthalazine $12(83 \mathrm{mg}, 72 \%)$ as a colorless viscous oil. ${ }^{1} \mathrm{H}$ NMR $\left(300 \mathrm{MHz}, \mathrm{CDCl}_{3}\right) \delta$ (ppm): $9.36(\mathrm{~s}, 1 \mathrm{H}), 7.75(\mathrm{~d}, J=9.0 \mathrm{~Hz}, 1 \mathrm{H}), 7.54(\mathrm{dd}, J=2.1,9.0 \mathrm{~Hz}, 1 \mathrm{H}), 7.46(\mathrm{t}, J=7.9$ $\mathrm{Hz}, 2 \mathrm{H}), 7.27(\mathrm{tt}, J=1.1,7.4 \mathrm{~Hz}, 1 \mathrm{H}), 7.21-7.12(\mathrm{~m}, 5 \mathrm{H}), 6.99(\mathrm{~s}, 1 \mathrm{H}), 6.93(\mathrm{t}, J=8.7 \mathrm{~Hz}$, 
$2 \mathrm{H}), 3.97(\mathrm{~s}, 3 \mathrm{H}), 3.94(\mathrm{~s}, 2 \mathrm{H}), 3.81(\mathrm{~s}, 3 \mathrm{H}), 3.60(\mathrm{~s}, 3 \mathrm{H}) \cdot{ }^{13} \mathrm{C} \mathrm{NMR}\left(75 \mathrm{MHz}, \mathrm{CDCl}_{3}\right) \delta$ (ppm): $161.2(\mathrm{~d}, J=243.8 \mathrm{~Hz}), 160.8,154.7,153.0,150.7,146.3,136.3(\mathrm{~d}, J=3.2 \mathrm{~Hz})$, $130.5,130.3,130.2$ (d, $J=7.9 \mathrm{~Hz}$ ), 129.3, 128.3, 126.4, 125.6, 125.3, 124.8, 122.4, 120.5, $115.0(\mathrm{~d}, J=21.2 \mathrm{~Hz}), 109.5,61.6,60.8,60.7,35.2 .{ }^{19} \mathrm{~F} \mathrm{NMR}\left(282.4 \mathrm{MHz}, \mathrm{CDCl}_{3}\right) \delta(\mathrm{ppm})$ : $-11 \sqsubset \square$ HRMS $\left(\mathrm{ESI}^{+}\right): \mathrm{C}_{30} \mathrm{H}_{25} \mathrm{FN}_{2} \mathrm{O}_{4} \mathrm{Na}[\mathrm{M}+\mathrm{Na}]^{+} \mathrm{m} / z$; calc: 519.1696, found: 519.1693.

\subsection{9 preparation of 4-(4-fluorobenzyl)-6-(6-phenoxyphthalazin-1-yl)benzene- 1,2,3-triol (2)}

To a stirred solution of compound $12(68 \mathrm{mg}, 0.14 \mathrm{mmol})$ was added dropwise $\mathrm{BBr}_{3}(1.4 \mathrm{ml}$, 10 eq., $1 \mathrm{M}$ in $\left.\mathrm{CH}_{2} \mathrm{Cl}_{2}\right)$ in $\mathrm{CH}_{2} \mathrm{Cl}_{2}(5 \mathrm{~mL})$ at $-78^{\circ} \mathrm{C}$ under nitrogen. The reaction mixture was allowed to warm up to rt and stirred overnight. The mixture was quenched with $\mathrm{MeOH}$. After evaporation of the solvent to dryness, the residue was recrystallized from a $7 / 3$ mixture of pentane $/ \mathrm{CHCl}_{3}$ to afford $2(50 \mathrm{mg}, 80 \%)$ as a yellow solid. MP: $177-179{ }^{\circ} \mathrm{C}$ (dcp.). ${ }^{1} \mathrm{H} \mathrm{NMR}$ (300 MHz, Acetone $\left.\mathrm{D}_{6}\right) \delta(\mathrm{ppm}): 9.71(\mathrm{~s}, 1 \mathrm{H}), 8.48(\mathrm{~d}, J=9.2 \mathrm{~Hz}, 1 \mathrm{H}), 8.01(\mathrm{dd}, J=2.4,9.2$ $\mathrm{Hz}, 1 \mathrm{H}), 7.80(\mathrm{~d}, J=2.4 \mathrm{~Hz}, 1 \mathrm{H}), 7.61(\mathrm{t}, J=7.8 \mathrm{~Hz}, 2 \mathrm{H}), 7.43(\mathrm{tt}, \mathcal{J}=1.1,7.4 \mathrm{~Hz}, 1 \mathrm{H}), 7.39$ $7.30(\mathrm{~m}, 4 \mathrm{H}), 7.01(\mathrm{t}, J=8.9 \mathrm{~Hz}, 2 \mathrm{H}), 6.95(\mathrm{~s}, 1 \mathrm{H}), 3.97(\mathrm{~s}, 2 \mathrm{H}) .{ }^{13} \mathrm{C}$ NMR $(100 \mathrm{MHz}$, Acetone $\left.\mathrm{D}_{6}\right) \delta(\mathrm{ppm}): 167.7,163.2(\mathrm{~d}, J=241.8 \mathrm{~Hz}), 159.2,155.8,153.3,151.2,145.6,138.9$ $(\mathrm{d}, J=3.1 \mathrm{~Hz}), 135.8,135.4,134.3,132.7,132.4$ (d, $J=7.8 \mathrm{~Hz}), 129.0,128.4,128.4,125.4$, 125.0, 123.5, 122.9, $116.6(\mathrm{~d}, J=21.2 \mathrm{~Hz}), 113.2,36.1{ }^{19} \mathrm{~F}$ NMR $\left(282.4 \mathrm{MHz}\right.$, Acetone $\left.\mathrm{D}_{6}\right) \delta$ (ppm): $-11 \square 2$. HRMS (ESI $\left.{ }^{+}\right): \mathrm{C}_{27} \mathrm{H}_{20} \mathrm{FN}_{2} \mathrm{O}_{4}[\mathrm{M}+\mathrm{H}]^{+} \mathrm{m} / z$; calc: 455.1407, found: 455.1405 .

\subsection{BRET assay:}

For BRET quantification assays, Hela cells were seeded on 6-well plates and transfected with pRLuc-Bax coding for BRET donor and peYFP-Bcl-xL coding for BRET acceptor (or with pCMV-Bcl-xL for control). A single donor/acceptor ratio (200ng/1000ng) was used to carry out the drug treatment assay. Twenty-four hours after transfection, cells were trypsinized and re-seeded into white 96 flat well plate, incubated for another day, and then treated with drugs for 16 hours at $10 \mu \mathrm{M}$ before measurment. Light emission at $485 \mathrm{~nm}$ and $530 \mathrm{~nm}$ was measured consecutively by using the Mithras fluorescence-luminescence detector LB 940 (Berthold) after adding the luciferase substrate, coelenterazine $\mathrm{H}$ (Uptima) at a final

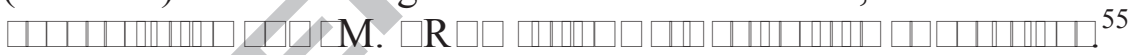

\subsection{Immunoprecipitation:}

Mcf7 cells were co-transfected with pCMV-Bcl-xL and pCMV-Bax plasmids, then treated overnight with $10 \mu \mathrm{M}$ of each compound as stated in the figure (9B). Immunoprecipitation assays were performed on $500 \mathrm{mg}$ of sonicated PBS-1\% CHAPS lysat using Bcl-xL antibody (Epitomics) or flag antibody for control I.P.(Sigma). After overnight incubation at $4^{\circ} \mathrm{C}$, antibodies were captured by A/G mix magnetic beads (Millipore) according to manufacturer's instructions. Following denaturing elution, samples were submit to SDS page, blotted, and incubated with either Bax antibody (Dako), Actin (Millipore) or the aforementioned Bcl-xL antibody. Membranes were eventually revealed using Clean Blot IP detection (ThermoScientific).

\section{Acknowledgments}


We thank Laboratoires Servier and Société de Chimie Thérapeutique for a fellowship to V. D. D. We thank the Ligue contre le Cancer for support to this research. We thank CNRS, INSERM, University of Rennes 1 and University of Nantes for financial support.

\section{Supplementary data}

Supplementary data associated with this article (characterization data: ${ }^{1} \mathrm{H}$ and ${ }^{13} \mathrm{C}$ NMR spectra for all new compounds) are available in the online version.

1 Mangani S (Ed.), Disruption of Protein-Protein Interfaces. In Search of New Inhibitors Springer, 2013, DOI 10.1007/978-3-642-37999-4

${ }^{2}$ V. Azzarito, K. Long, N. S. Murphy and A. J. Wilson, Inhibition of [alpha]-helix-mediated protein-protein interactions using designed molecules, Nat Chem, 5 (2013) 161-173.

${ }^{3}$ B. Villoutreix, C. F.-L. Labbe, D, D. F.-L. Lagorce, G, G. F.-S. Laconde, O and O. L.-e. P.J. A. P.-R. P.-N. T.-C. P. D. J.-C. p. d. J.-R.-. Sperandio, A leap into the chemical space of protein-protein interaction inhibitors. Curr Pharm Des 18 (2012) 4648-67.

${ }^{4}$ A. A. Ivanov, F. R. Khuri and H. Fu, Targeting protein-protein interactions as an anticancer strategy, Trends in Pharmacological Sciences, 34 (2013) 393-400.

${ }^{5}$ M. Krajewska, H. Kim, C. Kim, H. Kang, K. Welsh, S.-i. Matsuzawa, M. Tsukamoto, R. G. Thomas, N. Assa-Munt, Z. Piao, K. Suzuki, M. Perucho, S. Krajewski and J. C. Reed, Analysis of Apoptosis Protein Expression in Early-Stage Colorectal Cancer Suggests Opportunities for New Prognostic Biomarkers, Clinical Cancer Research, 11 (2005) 54515461.

${ }^{6}$ S. Yoshimine, E. Kikuchi, T. Kosaka, S. Mikami, A. Miyajima, Y. Okada and M. Oya, Prognostic significance of Bcl-xL expression and efficacy of Bcl-xL targeting therapy in urothelial carcinoma, Br J Cancer, 108 (2013) 2312-2320.

${ }^{7}$ W. H. Wilson, O. A. O'Connor, M. S. Czuczman, A. S. LaCasce, J. F. Gerecitano, J. P. Leonard, A. Tulpule, K. Dunleavy, H. Xiong, Y.-L. Chiu, Y. Cui, T. Busman, S. W. Elmore, S. H. Rosenberg, A. P. Krivoshik, S. H. Enschede and R. A. Humerickhouse, Navitoclax, a targeted high-affinity inhibitor of BCL-2, in lymphoid malignancies: a phase 1 doseescalation study of safety, pharmacokinetics, pharmacodynamics, and antitumour activity, The Lancet Oncology, 11 (2010) 1149-1159.

${ }^{8}$ S. A. Amundson, T. G. Myers, D. Scudiero, S. Kitada, J. C. Reed and A. J. Fornace, An Informatics Approach Identifying Markers of Chemosensitivity in Human Cancer Cell Lines, Cancer Research, 60 (2000) 6101-6110.

9 J. Chen, S. Jin, V. Abraham, X. Huang, B. Liu, M. J. Mitten, P. Nimmer, X. Lin, M. Smith, Y. Shen, A. R. Shoemaker, S. K. Tahir, H. Zhang, S. L. Ackler, S. H. Rosenberg, H. Maecker, D. Sampath, J. D. Leverson, C. Tse and S. W. Elmore, The Bcl-2/Bcl-XL/Bcl-w Inhibitor, 
Navitoclax, Enhances the Activity of Chemotherapeutic Agents In Vitro and In Vivo, Molecular Cancer Therapeutics, 10 (2011) 2340-2349.

10 Billard, C. Molecular Cancer Therapeutics, 12 (2013) 1691-1700.

${ }^{11}$ S. Shangary and D. E. Johnson, Peptides Derived from BH3 Domains of Bcl-2 Family Members: A Comparative Analysis of Inhibition of Bcl-2, Bcl-xL and Bax Oligomerization, Induction of Cytochrome c Release, and Activation of Cell Death, Biochemistry, 41 (2002) 9485-9495.

${ }^{12}$ A. Letai, M. C. Bassik, L. D. Walensky, M. D. Sorcinelli, S. Weiler and S. J. Korsmeyer, Distinct BH3 domains either sensitize or activate mitochondrial apoptosis, serving as prototype cancer therapeutics, Cancer Cell, 2 (2002) 183-192.

${ }^{13}$ S. Shangary, C. L. Oliver, T. S. Tillman, M. Cascio and D. E. Johnson, Sequence and helicity requirements for the proapoptotic activity of Bax BH3 peptides, Molecular Cancer Therapeutics 3 (2004) 1343-1354

${ }^{14}$ L. Chen, S. N. Willis, A. Wei, B. J. Smith, J. I. Fletcher, M. G. Hinds, P. M. Colman, C. L. Day, J. M. Adams and D. C. S. Huang, Differential Targeting of Prosurvival Bcl-2 Proteins by Their BH3-Only Ligands Allows Complementary Apoptotic Function, Molecular Cell, 17 (2005) 393-403.

${ }^{15}$ T. Kuwana, L. Bouchier-Hayes, J. E. Chipuk, C. Bonzon, B. A. Sullivan, D. R. Green and D. D. Newmeyer, BH3 Domains of BH3-Only Proteins Differentially Regulate Bax-Mediated Mitochondrial Membrane Permeabilization Both Directly and Indirectly, Molecular Cell, 17 (2005) 525-535.

${ }^{16}$ L. D. Walensky, A. L. Kung, I. Escher, T. J. Malia, S. Barbuto, R. D. Wright, G. Wagner, G. L. Verdine and S. J. Korsmeyer, Activation of Apoptosis in Vivo by a Hydrocarbon-Stapled BH3 Helix, Science 305 (2004) 1466-1470.

${ }^{17}$ L. D. Walensky, K. Pitter, J. Morash, K. J. Oh, S. Barbuto, J. Fisher, E. Smith, G. L. Verdine and S. J. Korsmeyer, A Stapled BID BH3 Helix Directly Binds and Activates BAX, Molecular Cell, 24 (2006) 199-210.

${ }^{18}$ M. Leone, D. Zhai, S. Sareth, S. Kitada, J. C. Reed and M. Pellecchia, Cancer Prevention by Tea Polyphenols Is Linked to Their Direct Inhibition of Antiapoptotic Bcl-2-Family Proteins, Cancer Research Cancer Research 63 (2003) 8118-8121.

${ }^{19}$ S.-L. Chan, M. C. Lee, K. O. Tan, L.-K. Yang, A. S. Y. Lee, H. Flotow, N. Y. Fu, M. S. Butler, D. D. Soejarto, A. D. Buss and V. C. Yu, Identification of Chelerythrine as an Inhibitor of BclXL Function, Journal of Biological Chemistry, 278 (2003) 20453-20456.

${ }^{20}$ T. Oltersdorf, S. W. Elmore, A. R. Shoemaker, R. C. Armstrong, D. J. Augeri, B. A. Belli, M. Bruncko, T. L. Deckwerth, J. Dinges, P. J. Hajduk, M. K. Joseph, S. Kitada, S. J. Korsmeyer, A. R. Kunzer, A. Letai, C. Li, M. J. Mitten, D. G. Nettesheim, S. Ng, P. M. Nimmer, J. M. O'Connor, A. Oleksijew, A. M. Petros, J. C. Reed, W. Shen, S. K. Tahir, C. B. Thompson, K. J. Tomaselli, B. Wang, M. D. Wendt, H. Zhang, S. W. Fesik and S. H. 
Rosenberg, An inhibitor of Bcl-2 family proteins induces regression of solid tumours, Nature, 435 (2005) 677-681.

${ }^{21}$ S. Barelier, J. Pons, O. Marcillat, J.-M. Lancelin and I. Krimm, Fragment-Based Deconstruction of Bcl-xL Inhibitors, Journal of Medicinal Chemistry, 53 (2010) 2577-2588.

${ }^{22}$ Supplementary Fig. 1

${ }^{23}$ T. Clackson and J. Wells, A hot spot of binding energy in a hormone-receptor interface, Science, 267 (1995) 383-386.

${ }^{24}$ Guo, W.; Wisniewski, J. A.; Ji, H. Bioorganic \& Medicinal Chemistry Letters , 24 (2014) 2546-2554.

25 A. L. Hopkins, G. M. Keseru, P. D. Leeson, D. C. Rees and C. H. Reynolds, The role of ligand efficiency metrics in drug discovery, Nat Rev Drug Discov, 13 (2014) 105-121.

${ }^{26}$ A. Degterev, A. Lugovskoy, M. Cardone, B. Mulley, G. Wagner, T. Mitchison and J. Yuan, Identification of small-molecule inhibitors of interaction between the BH3 domain and Bcl$x L$, Nat Cell Biol, 3 (2001) 173-182.

${ }^{27}$ Y. Feng, X. Ding, T. Chen, L. Chen, F. Liu, X. Jia, X. Luo, X. Shen, K. Chen, H. Jiang, H. Wang, H. Liu and D. Liu, Design, Synthesis, and Interaction Study of Quinazoline-2(1H)thione Derivatives as Novel Potential Bcl-xL Inhibitors, J. Med. Chem., 53 (2010) 3465-3479.

${ }^{28}$ M. F. Rega, M. Leone, D. Jung, N. J. H. Cotton, J. L. Stebbins and M. Pellecchia, Structure-based discovery of a new class of Bcl-xL antagonists, Bioorganic Chemistry, 35 (2007) 344-353.

${ }^{29}$ S. Melkko, L. Mannocci, C. E. Dumelin, A. Villa, R. Sommavilla, Y. Zhang, M. G. Grütter, N. Keller, L. Jermutus, R. H. Jackson, J. r. Scheuermann and D. Neri, Isolation of a SmallMolecule Inhibitor of the Antiapoptotic Protein Bcl-xL from a DNA-Encoded Chemical Library, ChemMedChem, 5 (2010) 584-590.

${ }^{30}$ B. Zhou, X. Li, Y. Li, Y. Xu, Z. Zhang, M. Zhou, X. Zhang, Z. Liu, J. Zhou, C. Cao, B. Yu and R. Wang, Discovery and Development of Thiazolo[3,2-a]pyrimidinone Derivatives as General Inhibitors of Bcl-2 Family Proteins, ChemMedChem, 6 (2011) 904-921.

${ }^{31} \mathrm{WO} 2010 / 080503$

${ }^{32}$ G. Tang, K. Ding, Z. Nikolovska-Coleska, C.-Y. Yang, S. Qiu, S. Shangary, R. Wang, J. Guo, W. Gao, J. Meagher, J. Stuckey, K. Krajewski, S. Jiang, P. P. Roller and S. Wang, Structure-Based Design of Flavonoid Compounds As a New Class of Small-Molecule Inhibitors of the Anti-apoptotic Bcl-2 Proteins, J. Med. Chem., 50 (2007) 3163-3166.

${ }^{33}$ S. Kitada, M. Leone, S. Sareth, D. Zhai, J. C. Reed and M. Pellecchia, Discovery, Characterization, and Structure-Activity Relationships Studies of Proapoptotic Polyphenols Targeting B-Cell Lymphocyte/Leukemia-2 Proteins, J. Med. Chem., 46 (2003) 4259-4264. 
${ }^{34}$ J. Wei, S. Kitada, J. L. Stebbins, W. Placzek, D. Zhai, B. Wu, M. F. Rega, Z. Zhang, J. Cellitti, L. Yang, R. Dahl, J. C. Reed and M. Pellecchia, Synthesis and Biological Evaluation of Apogossypolone Derivatives as Pan-active Inhibitors of Antiapoptotic B-Cell Lymphoma/Leukemia-2 (Bcl-2) Family Proteins, J. Med. Chem., 53 (2010) 8000-8011.

${ }^{35}$ M. Pinto, M. del Mar Orzaez, L. Delgado-Soler, J. J. Perez and J. Rubio-Martinez, Rational Design of New Class of BH3-Mimetics As Inhibitors of the Bcl-xL Protein, J. Chem. Inf. Model., 51 (2011) 1249-1258.

${ }^{36}$ G. Moroy, E. Martin, A. Dejaegere and R. H. Stote,Molecular Basis for Bcl-2 Homology 3 Domain Recognition in the Bcl-2 Protein Family: IDENTIFICATION OF CONSERVED HOT SPOT INTERACTIONS, Journal of Biological Chemistry, 284 (2009) 17499-17511.

${ }^{37}$ D. Kozakov, D. R. Hall, G.-Y. Chuang, R. Cencic, R. Brenke, L. E. Grove, D. Beglov, J. Pelletier, A. Whitty and S. Vajda, Structural conservation of druggable hot spots in proteinprotein interfaces, Proceedings of the National Academy of Sciences, 108 (2011) 1352813533.

${ }^{38}$ D. R. Hall, C. H. Ngan, B. S. Zerbe, D. Kozakov and S. Vajda, Hot Spot Analysis for Driving the Development of Hits into Leads in Fragment-Based Drug Discovery, J. Chem. Inf. Model., 52 (2011) 199-209.

39 J. L. Kulp, J. L. Kulp, D. L. Pompliano and F. Guarnieri, Diverse Fragment Clustering and Water Exclusion Identify Protein Hot Spots, J. Am. Chem. Soc., 133 (2011) 10740-10743.

${ }^{40}$ A. Miranker and M. Karplus, Functionality maps of binding sites: A multiple copy simultaneous search method, Proteins: Structure, Function, and Bioinformatics, Proteins, 11 (1991) 29-34.

41 P. Hajduk, Fragment-Based Drug Design: How Big Is Too Big?, J. Med. Chem., 49 (2006) 6972-6976.

42 Zhang, Z.; Song, T.; Li, X.; Wu, Z.; Feng, Y.; Xie, F.; Liu, C.; Qin, J.; Chen, H. European Journal of Medicinal Chemistry, 59 (2013) 141-149.

${ }^{43}$ G. Tang, Z. Nikolovska-Coleska, S. Qiu, C.-Y. Yang, J. Guo and S. Wang, Acylpyrogallols as Inhibitors of Antiapoptotic Bcl-2 Proteins, J. Med. Chem., 51 (2008) 717-720.

${ }^{44}$ D. D. Vo, F. Gautier, S. Barillé-Nion, P. Juin, N. Levoin and R. Grée, Synthesis of new mixed phenol/heterocyclic derivatives and studies of their activity as inhibitors of Bax/Bcl-xL interaction, Tetrahedron, 70 (2014) 301-311.

${ }^{45}$ D. D. Vo, F. Gautier, P. Juin and R. Grée, Structure-activity relationship of selected polyphenol derivatives as inhibitors of Bax/Bcl-xL interaction, European Journal of Medicinal Chemistry, 51 (2012) 286-293.

${ }^{46}$ D. D. Vo, F. Gautier, S. Barillé-Nion, P. Juin, N. Levoin and R. Grée, Design, synthesis and biological evaluation of new inhibitors of Bax/Bcl-xL interaction in cancer cells, Bioorganic \& Medicinal Chemistry Letters, 24 (2014) 1758-1761. 
47 S. A. Kumar; K. Minseob; P. S. Bum, A Synthetic Route to Highly Substituted 1,2,3,4Tetrahydroisoquinolines via Yb(OTf)3-Catalyzed Diastereoselective Ring Opening of Bridged Oxazolidines: Asymmetric Synthesis of 2-Azapodophyllotoxin, Chemistry - A European Journal 17 (2011) 4905-4913.

${ }^{48}$ A. J. Wilson, Inhibition of protein-protein interactions using designed molecules, Chem. Soc. Rev., 38 (2009) 3289-3300.

${ }^{49}$ W. Feng, S. Huang, H. Wu and M. Zhang, Molecular Basis of Bcl-xL Target Recognition Versatility Revealed by the Structure of Bcl-xL in Complex with the BH3 Domain of Beclin-1, Journal of Molecular Biology, 372 (2007) 223-235.

${ }^{50}$ E. F. Lee, P. E. Czabotar, H. Yang, B. E. Sleebs, G. Lessene, P. M. Colman, B. J. Smith and W. D. Fairlie, Conformational Changes in Bcl-2 Pro-survival Proteins Determine Their Capacity to Bind Ligands, Journal of Biological Chemistry 284 (2009) 30508-30517

${ }^{51}$ S. Eyrisch and V. Helms, Transient Pockets on Protein Surfaces Involved in ProteinProtein Interaction, J. Med. Chem., 50 (2007) 3457-3464.

${ }^{52}$ E. F. Lee, P. E. Czabotar, B. J. Smith, K. Deshayes, K. Zobel, P. M. Colman and W. D. Fairlie, Crystal structure of ABT-737 complexed with Bcl-xL: implications for selectivity of antagonists of the Bcl-2 family, Cell Death Differ, 14 (2007) 1711-1713.

${ }^{53}$ G. Wang, Z. Nikolovska-Coleska, C.-Y. Yang, R. Wang, G. Tang, J. Guo, S. Shangary, S. Qiu, W. Gao, D. Yang, J. Meagher, J. Stuckey, K. Krajewski, S. Jiang, P. P. Roller, H. O. Abaan, Y. Tomita and S. Wang, Structure-Based Design of Potent Small-Molecule Inhibitors of Anti-Apoptotic Bcl-2 Proteins, J. Med. Chem., 49 (2006) 6139-6142.

${ }^{54}$ M. K. Haider, H.-O. Bertrand and R. E. Hubbard, Predicting Fragment Binding Poses Using a Combined MCSS MM-GBSA Approach, J. Chem. Inf. Model., 51 (2011) 1092-1105.

${ }^{55}$ Terrillon, S.; Durroux, T.; Mouillac, B.; Breit, A.; Ayoub, M.A.; Taulan, M.; Jockers, R.; Barberis, C.; Bouvier, M. Oxytocin and vasopressin V1a and V2 receptors form constitutive homo- and heterodimers during biosynthesis. Mol. Endocrinol. 17 (2003) 677-691. 


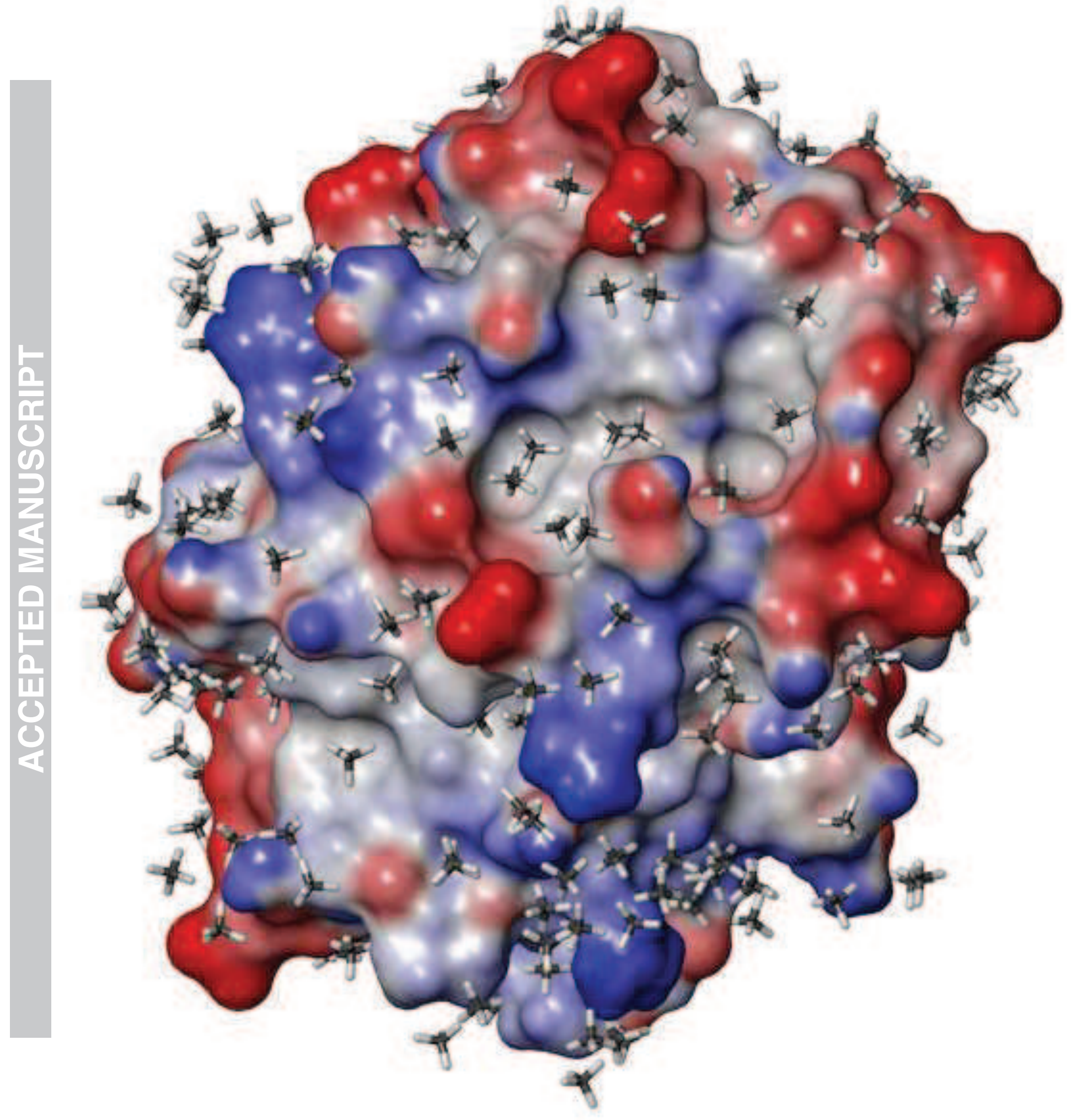

${ }_{B}$ 